\title{
Law in Time: Legal Theory and Legal History
}

\section{Paulo Barrozo*}

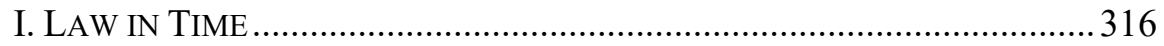

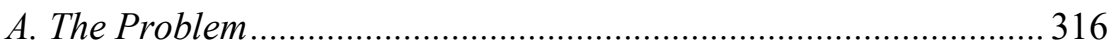

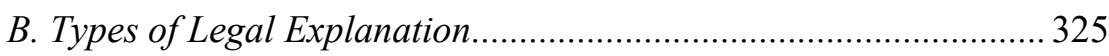

C. History of Law as Diachronic Explanation ................................... 328

II. THEORY OF THE NATURE AND EVOLUTION OF LAW ...........................339

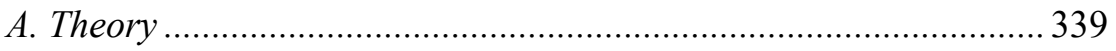

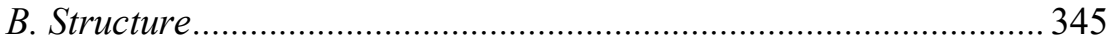

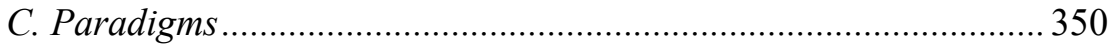

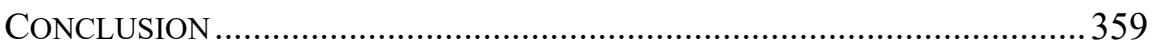

\section{LAW IN TIME}

\section{A. The Problem}

Over a long period, simple societies achieved social stability as social stasis through normative inertia. ${ }^{1}$ Conversely, high-complexity ${ }^{2}$ societies

\footnotetext{
* Associate Professor of Law, Boston College Law School. I gratefully acknowledge the outstanding assistance of Deepika Kommineni and the support of the Boston College Law School Fund.

1. Note two points here. First, the obvious distinction between stability and stasis. The achievement of stability by high-complexity societies was only possible by doing away with stasis. Relatedly, social stability and instability and normative inertia and change are spectrum phenomena. Whenever they are mentioned, the qualifications "relative" or "sufficient" are implicit. Second, and implicit in the causal structure of the phrase footnoted here, society is norms through and through.

2. If we translate "elements" into "systems", systems theory is unusually helpful in identifying the tipping-point phenomenon in question: "evolution ... does not halt the growth of systems at the point from which it is no longer possible to connect every element with every other element at any time.... The key distinction is now between systems with complete interconnection between elements and those with only selective interconnection; and the real systems of the evolved world are obviously to be found on the latter side of the distinction. In brief, the form of complexity is hence the necessity to sustain an only selective connection between elements, in other words, the selective organization of the system's autopoiesis." 1 NiKLAS LuHMANN, THEORY OF SOCIETY, 79-80 (Rhodes Barrett trans., Stanford Univ. Press 2012). The approach to complexity that remains largely implicit in this Article is otherwise markedly distinct from systems theory analysis of complexity in general and law's complexity, as an
} 
achieve - when they do-social stability as constant functional adaptation and axiological responsiveness through small quotidian and large occasional normative changes. ${ }^{3}$

Stability is a sociological concept. Order is a normative one. Order denotes stability normatively produced and sustained. As a normative concept, order is susceptible to further normative specifications in terms of, e. g., sacredness or profanity, authenticity or inauthenticity, justice or injustice.

Order in simple societies is the result of normative inertia, while order in high-complexity societies is brought about by constant normative change. ${ }^{4}$ To understand order in both types of societies is to begin to understand the question of law in time.

For the argument of this Article, the concept of high-complexity societies requires no more than a working definition. Societies are complex by virtue of their demographic, economic, institutional, cultural, political, geopolitical, cognitive, technological, self-referential, and communicative elements each reaching both qualitative and quantitative thresholds. The specification of these thresholds is constrained only by rational persuasion in the context of the complexity model that incorporates them. The moment these elements all reach their respective thresholds, their interrelationship activates the transformation in societal type from complex to highly complex, with significant implications for social order.

Not all high-complexity societies develop legal systems. In those that do, ${ }^{5}$

"emergent" and "self-organizing" system, in particular. In addition to Luhmann's work, see the essays collected in JAMIE MURRAY, COMPLEXITY THEORY AND LAW: MAPPING AN EMERGENT JURISPRUDENCE (Thomas E. Webb \& Steven Wheatley eds., 2019).

3. This question may be asked from within normative orders. In a classical example, "how is it possible for there to exist over time a just and stable society of free and equal citizens who still remain profoundly divided by reasonable religious, philosophical, and moral doctrines?" JOHN RAWLS, POLITICAL LIBERALISM (1999). For an incisive argument about how "reasonability" anchors the central theses of Rawls' novel liberal approach to his question see David Rasmussen, Defending Reasonability: The Centrality of Reasonability in the Later Rawls, 30 Phil. \& Soc. Criticism 5-6 (2004). In the conceptual framework presented below, legal liberalism is an enclosed-diachronic type of legal thought. Note also the discussion at the end of the problem of "reflection versus commitment." On the responsiveness of legal orders, see Vlad Perju, Cosmopolitanism and Constitutional Self-Government, in 8 INT'L J. CONST. L. 3 (2010).

4. Conservatism and progressivism are clusters of political intuitions, sensibilities, and attitudes intelligible only against a background of social order. That order is a primary social good necessary for the achievement and enjoyment of other goods tends to remain opaque to progressives, while conservatives fail to understand that constant progress is what order requires in high complexity societies. That conservatism and progressivism will remain politically relevant in high complexity societies does not make them less sociologically and normatively immature.

5. See, for the preeminent comparative historical analysis of the evolutionary path from "customary law" through "bureaucratic law" into "legal systems," ROBERTO MANGABEIRA UNGER, LAW IN MODERN SOCIETY: TOWARD A CRITICISM OF SOCIAL THEORY (1977), and, for extended analyses of the concept of legal systems, HANS KELSEN, PURE THEORY OF LAW (Max Knight trans., Univ. of Cal. Press 1967); H.L.A. HART, THE CONCEPT OF LAW (2012); JosePh RAZ, THE CONCEPT OF A LEGAL SySTEM (1980); Noberto Bobbio, Dalla Struttura Alla Funzione: Nuove Studi Di Teoria Del DIRITTO (Laterza ed., 2007). For adjudication as part of legal systems, see the classics RONALD Dworkin, LAW's EMPIRE (1986); and DunCAN KENNEDY, A CRITIQUE OF ADJUDICATION (FIN DE 
ever-larger expanses of social normativity are institutionalized as law. ${ }^{6}$ Also institutionalized as law ${ }^{7}$ in those societies are adaptive responses to coordination problems themselves, which are largely created by complexification itself. This both normative and adaptive institutionalization process connects the universality of law as an institution to law's expansionist voracity. ${ }^{8}$

There is no single formal source of law that consistently predominates in the process of normative and adaptive institutionalization. It varies. For example, citizens' disillusionment with representative government may channel their demands to the judiciary, giving this branch the lead in the process of institutionalization of not-yet-institutionalized normativity as well as of managerial solutions. ${ }^{9}$ In any event, law responds with gulping voracity to aspiration as well as adaptation.

Thus, in the ongoing institutionalization of normativity and adaptability, social stability as constant normative change is as much a sociological as it is an ethical achievement of legal systems.

The sociological feat is obvious: the production of social cohesion over time for large populations. The ethical achievement lies in the fact that while real or perceived social coordination problems raise tail-wind pressures for functional adaptation, axiological orientations call on values ${ }^{10}$ to inform the attitude and behavior of legal actors involved in functional adaptation. The impact of values takes the form at times of a blazing edge steering the direction of functional adaptation, at other times of sources themselves of social pressures in the form of legitimacy challenges or crises. ${ }^{11}$ Equally important is the fact that any steering by values is already in some degree present in the value-laden mediation of legal actors' diagnosis as well as their response to adaptation pressures. Hence, if in their

\footnotetext{
SIECLE) (1998).

6. In an example, in a brilliant study of "trust among strangers" in the context of large demographic, economic and urban changes in a rapidly complexifying Britain, Penelope Ismay shows how intermediary civil associations adapted to develop notions and embody practices of collective responsibility ("of who owes what to whom and why"). The normative kernel of those notions and practices was in time voraciously institutionalized by British welfare law. See PENELOPE ISMAY, TRUST AMONG STRANGERS: Friendly SOCIETIES IN MODERN BRITAIN (2018).

7. Institutions channel behavior into transtemporal patterns.

8. Of the phenomenon of law's constant expansion, Hayek saw only the dimension of its functional adaptation through pressure groups influence, therefore missing the independent weight of its axiological component. 1-3 FRIEDRICH A. HAYEK, LAW, LEGISLATION, AND LIBERTY (1978-81). This oversight has plagued the schools of legal, economic and political thought influenced by him.

9. For insightful analysis of this process in a high-energy democracy, see LUIS RoBERTO BARROSO, A Judicializacao Da Vida E O PAPEl Do Supremo Tribunal Federal, 45 (2018). See also 240 ANA Paula De Barcellos, Neoconstitucionalismo, Direitos Fundamentais E Controle Das Politicas Publicas, 83-103 (Direito Administrativo ed., 2005); MAlcolm M. FeEley \& Edward L. Rubin, Judicial Policy MAKING AND THE MODERn STATE (2000).

10. This framework rejects as reductionist and distorting efficiency-based approaches to the "evolution" of common law, from Ronald Coase to Richard Posner and beyond.

11. See groundbreaking analysis in JURGEN HABERMAS, Legitimation CRisis (Thomas McCarthy transl., Beacon Press 1975).
} 
long historical arc it seems that the legal systems of high-complexity societies move in the direction of certain ideals, ${ }^{12}$ it is because they do.

Ultimately, though, legal systems are able to constitute the type of order characterized by social stability as constant normative change only inasmuch as legal actors internalize, act out and act upon a paradigm of law in a way that smooths out inescapable and irreducible functional-axiological tensions.

I say more about paradigms in Subsection 2(C). For now, assume that it is through the operation of paradigms of legal thought that legal systems can be the vessels in which adaptation and aspiration fare a chance of travelling together through time in the form of law. ${ }^{13}$ And as the law of high complexity societies unfolds in time, it is only because of paradigms of legal thought that legal systems are able to assume what is often referred to as their autopoietic - significantly self-referential, self-reproducing, and selfvalidating - and autotelic (formalist) capabilities. The upshot for legal historians is that any kind of legal history fails adequately to account for the viewpoint of legal actors unless it incorporates in its narrative the way in which paradigms shape thoughts and attitudes.

Now, even this précis of a theory of law in time already burdens legal history in important ways. If we define the history of law as the narrativestructured, ${ }^{14}$ retrospective, ${ }^{15}$ diachronic explanation of law in time, what epistemological, ontological and stability/change models set legal history apart from mere stories about law, as both take on the retrospective narrative form that has law as its object? Unaided by a general theory of the nature of law and its evolution, what justifiable basis is there for setting those standards? What basis is there for selecting the ideas, sources, institutions, actors, and events ${ }^{16}$ in social stability and instability and in normative inertia

12. Of course, the ideals of liberal, democratic, and capitalist societies do not exhaust the constellation of ideals that have animated high-complexity societies, even those that eventually developed legal systems.

13. Realization of the inescapable, and ultimately irreducible, tension between adaptation and aspiration goes back to Weber and, before him, to Hegel and Hobbes. The 1970's saw important liberal and critical work on the dialectic of functions and values. See, among several, JOHN RAWLS, A THEORY OF JUSTICE (1971); Duncan Kennedy, Legal Formality, 2 J. Legal Stud. 351 (1973); Jurgen Habermas, Legitimation CRisis (1973); Roberto MANGABEIRA Unger, KNOWLEdGE AND Politics (1975); UnGER, supra note 5; and David M. Trubek, Complexity and Contradiction in the Legal Order: Balbus and the Challenge of Critical Social Thought about Law, in 11 LAW \& SOC'Y REV. 529 (3d ed. 1977).

14. For a collection of interventions in the controversies on history and/as narrative, see THE HISTORY AND NARRATIVE READER (Geoffrey Roberts ed., 2001).

15. This is not a pleonasm, as prospective explanations are also diachronic.

16. "Event" is not used here to mean being subject to causality as opposed to being subject to reason, as in Collingwood's distinction between event and action. Events here mean primarily human engendered occurrences deemed to cause one of the dents in the fabric of human affairs by which we measure time. See R. G. COLlingwoOd, The IDEA OF History (1994). The same point can be made in Dilthey's 
and change that make up the materials of the history of law as distinguished from the elements of the history of something else? What basis is there for the detection and identification of paradigms of legal thought, and for the explanation of their content and operation? Furthermore, as previous legal history is itself an object of historical inquiry, ${ }^{17}$ each generation of historians writes, in endless revisionisms, its own retrospective diachronic narrative about the legal historical narratives of preceding generations. Thus, what justifiable basis is there for the purported rectifications of revisionism without the aid of a general theory?

The threshold question for the legal history of high-complexity societies is, therefore, this: what conception of the nature and evolution of law supports its selection and interpretation of legal materials, institutions, events, conducts and attitudes? ${ }^{18}$

Furthermore, how legal actors interface with legal historiography raises an independent jurisprudential question: what role does the discipline of legal history play in the evolution of law? More specifically, what role does legal history, including critical legal history, ${ }^{19}$ play in the social order of high complexity societies?

While legal historians are charged with the reflective adoption of an answer to legal history's threshold question, they may well remain unencumbered by the question of the role legal history plays in the evolution of law. Hence this Article prioritizes the first question, that is, on legal theory for legal history. Only secondarily does it address the question of legal history's evolutionary role.

This Article makes use of connected premises of theoretical construction. The first premise is that law is the one universal institution, for there is no individual who is not a legal person and no planetary space that is not a legal

terms: events are expressions of human experience deemed important, the proper account of which is by reconstructing in the thought of the historian the experience - made available by verstehen - of the actors of the event. See WiLHELM DiLTHEY, HERMENEUTICS AND THE STUDY OF HiSTORY 4 (Rudolf A. Makkreel and Frijhthof Rodi eds., 1996).

17. See, as examples of histories of legal history, J. G. A. Pocock, THE ANCIENT CONSTITUTION AND the Feudal LaW (1987); Peter Stein, Legal Evolution (2009); Donald R. Kelly, The Human MeAsure: Social Thought in the Western Legal Tradition (1990).

18. Although clear already, later in this Article it will become clearer why and how the theory of the nature and evolution of law that legal history ought to rely upon is nothing like the naïve "evolutionary functionalism" critical legal history has attacked as underlying much of apologetic legal history. See Robert W. Gordon, Critical Legal Histories, 36 STAN. L. REV. 57, (1984) as republished in ROBERT W. GORDON, TAMING THE PAST: ESSAYS ON LAW IN HiSTORY AND HiSTORY IN LAW (2017).

19. Critique may come from conservative as well as progressive camps, both of which are well represented in modern historiography. The ideal of critical legal history that inspires this Article refers however to a historiography preoccupied with its conditions of epistemic possibility as well as with denouncing justificatory practices that have not earned their persuasiveness in favor of structures and practices of domination and exclusion. 
space, and no person or space is outside the law. This no other institution can match. And as domestic legal systems connect to each other transnationally and to the system of international law in inextricable myriad ways, the connectivity of law furthers its universality. Therefore, legal history, even that which focuses on topics parochial in space or in time, ${ }^{20}$ touches a dimension of the universal. ${ }^{21}$ We must add to the universality of legal history's object the latent universalism of the historical narrative form itself, whose explanatory scope would forever expand-as the web of phenomenal relatedness is endlessly interwoven-were it not limited by convention or by ontological or causal pre-commitments.

Thus, finding itself in the realm of the institutional and discursive universal, legal history is gifted an equally universal epistemic opportunity: that of explaining how the universal touches the historical ground, and is in turn bounced back, reshaped, to the realm of the universal. But there too lies a challenge that legal history shares with other areas of historiography. Excluding the reconstruction of the enduring problematics of reason or for geistesgeschichtlich histories of high thought, ${ }^{22}$ much of historiography remains overwhelmed by the nation and the categories of nationalism, ${ }^{23}$ despite renewed calls, every couple of generations, for global, transnational, deep or long-term history. ${ }^{24}$ Both apologetic and critical legal histories commit this ideological sin of cognition. Therefore, a condition legal history must meet in order to thrive in the realm of the universal while walking the ground of particular manifestations is its methodological use of general theories of the nature and evolution of law without which that which touches on everything everywhere (law) cannot be properly segregated for study

20. I explain what I mean by parochialism of space and time in Paulo Barrozo, Institutional Conditions of Contemporary Legal Thought, in SEARCHING FOR CONTEMPORARY LEGAL THOUGHT (Christopher Tomlins \& Justin Desautels-Stein eds., 2017).

21. Even as history is methodologically concerned with objects concrete and particular, as contrasted to abstract and universal. See COLLINGWOOD, supra note 16. Or even as legal history is conceived as "remainder," as recovering "traces" in the realm of "equivalents" that law creates. See Christopher Tomlins, Why Law's Objects do not Disappear, in RouTLEDGE HANDBOOK OF LAW AND THEORY (Andreas Philippopoulos-Mihalopoulos ed., 2019). For a classical locus of critique of law's creation of equivalences at the cost of disembodying abstractions, see Karl Marx, On the Jewish Question, in MARX: EARLY POLITICAL Writings (Joseph O’Malley \& Richard A. Davis trans., Cambridge Univ. Press 1994).

22. See, e.g., G. W. F. Hegel, Elements of the Philosophy of Right $\S 341-60$ (1920). See, for a helpful typology of history of thought, Richard Rorty, The Historiography of Philosophy: Four Genres, in PHILOSOPHY IN History: EsSAys IN THE HistoriogRAPHY OF PHILOSOPHY (Richard Rorty et al. eds., 1984).

23. And with it the temptation of reading "the national past solely from an insider's perspective." AzIZ RANA, THE Two FACES OF AMERICAN FREEDOM 6 (2010).

24. Among the most recent (previous summons to "longue durée" and to "universal" history date back to the 1950's-1970's), see Jo GULDI \& DAVID ARMitAGE, THE History OF MANifESTO (2014) (and a reaction to it in Markus Dubber, New Historical Jurisprudence: Legal History as Critical Analysis of Law, in CRITICAL ANALYSIS OF LAW 2:1 (2015)); LYNN HUNT, WRITING HiSTORY IN THE GLOBAL ERA (2015); JuRgen OSTERHAMMEL, THE TRANSFORMATION OF THE WORLD: A GlOBAL History of THE Nineteenth Century (Patrick Camiller trans., Princeton Univ. Press 2015); and SEBASTIAn ConRaD, WHAT IS GLOBAL HisTORY? (2016). 
from what is touched by it. ${ }^{25}$

The second premise is that determinations of historiographical relevance are unavoidable. The only question is the degree to which they are justifiable.

To see those determinations as unavoidable it to disavow the view of legal history as the assembly of a diachronic puzzle that is epistemologically and ontologically framed by mind-independent time, causation and events of law. Because, rather, law's time, causation and events are constituted as such and measured by how jurists and legal historians select from the unrecoverable entirety of the past the ideas, paradigms, sources, institutions, actors, attitudes, and events that legal history narratively weaves together in present meaning and intelligibility. ${ }^{26}$

Augustine's arcane insight on the grasping of time only by virtue of the mental appropriation of events in time is illuminating here: "Tis in thee, $\mathrm{O}$ my mind, that I measure my times.... The impression, which things passing by cause in thee, and remains even when the things are gone, that is it which being still present, I do measure: not the things which have passed by that this impression might be made." 27 The upshot here is that the selectivity of past events is both unavoidable and constitutive of the very diachronicity of legal history. ${ }^{28}$ The only concern is whether determinations of historiographical relevance by legal history are grounded on a theory of the nature and evolution of law. When it is not, legal history risks dilettantism.

This is not to say that dilettante legal history is unimportant or

25. Except for specific, sage, or record-setting history. Several examples of record-setting legal history come to mind: Victor Farias, HeidegGer E Le NAZiSME (1987); KeIla GrinBerg, LiBerATA, A LeI Da Ambiguidade: As acoes De Liberdade Da Corte De Apelacao Do Rio De Janeiro No SECUlO XIX (1994); Mary S. Bilder, The Corporate Origins of Judicial Review, 3 YALE L.J. 116 (2006) and Mary S. Bilder, Madison's Hand: Revising the Constitutional Convention (2017); DANiEl Kanstroom, Deportation NATION: Outsiders In AMERICAN History (2010); William E. Forbath, The Long Life of Liberal America: Law and State-Building in England and the U.S., 24 LAW \& Hist. REV. 179 (2006); Daniela Caruso \& Joanna Geneve, Trade and History: The Case of EUAlgeria Relations, 1 B. U. INT'L L.J. 33 (2015); and AMALIA D. KeSSLER, INVENTING AmERICAN EXCEPTIONAlism: The Origins of AMERICAN AdVERSARial Legal Culture, 1800-1877 (2017). Even specific legal history focused on the far past may open a keyhole through which to see aspects of the universal or the sempiternal. See Adrian Vermeule \& Adriaan Lanni, Precautionary Constitutionalism in Ancient Athens, 34 CARDOZO L. REV. 893 (2013).

26. For an influential typology of narrative motivations, see HAYDEN White, METAHISTORY: THE HistORICAL IMAGINATION IN NINETEENTH-CENTURY EUROPE (2014). A typology of historical frameworks offered to an audience of legal historians appears in Chapter 8 of REINHART KOSELLECK, SEDIMENTS OF TIME: ON POSSIBLE HISTORIES (2018). Typologies of kinds of history are classically offered by Hegel and Nietzsche. See, respectively, G. W. F. HEGEL, THE Philosophy OF History (J. Sibree Trans., Prometheus 1991) (1837); and Friedrich NiETZSCHE, ON THE Use AND Disadvantage OF History fOR LifE (Peter Preuss trans., Hackett 1980) (1873).

27. Augustine, Confessions, 273-274 (William Watts trans., Harvard U. Press 2006). Collingwood made the same point that the past no longer exists and the historian in a way studies the present, that is, traces in the present of the bygone, and from those traces builds narratives reconstructing the past. See COLLINGWOOD, supra note 16.

28. Selectivity of the past is rooted in the limits of cognition as well as in data access. That's what makes the selectivity unavoidable. 
uninteresting. As it will be shown below, legal history plays an important legal evolutionary role independently of its theoretical grounding. Furthermore, the humanistic, intimate, and personal-sage role that history often assumes for individuals in general ought not to be discounted. ${ }^{29}$

Neither is it to say that legal history fails unless it adopts a full-fledged theory of stability/change beyond its ordinary reliance on the antecedentensuing mold of historical prose. ${ }^{30}$ But grand legal history does require theoretical criteria minimally to sustain actor-focused interpretations and for sorting out the most relevant from the most irrelevant in its selectivity of the past.

Theoretically grounded determinations of historiographical relevance are especially important for modern critical historiography, for to reveal the justifiably relevant that has failed to be selected by apologetic historiography - and is therefore silenced-is one of its motifs, from Rousseau to Foucault. ${ }^{31}$ In any event, the second premise of the overall argument of this Article is that legal history is written from a present from which the past is reconstructed. This reconstruction is selective, and the selection should be well informed by a theory of the nature and evolution of law.

The third premise of the overall argument of this Article is that any account of the nature and evolution of law is fundamentally a conceptual enterprise. It is so not just because intelligibility at the level of theory construction thus requires. Conceptualism is required not only for intelligibility during theory construction, but also by the fact that legal actors orientate and operate in the world through concepts. Consequently, the selectivity of the past that history cannot avoid is ineludibly also about concepts and is undertaken through conceptual lenses. Historians eventually find that structured narratives that refer to objects outside the narrative can

29. In the words of a great humanist, "No reality is more essential to our self-awareness than history. It shows us the broadest horizons of mankind, brings us the contents of tradition upon which our life is built, shows us standards by which to measure the present, frees us from unconscious bondage to our own age, teaches us to see man in his highest potentialities and his imperishable creations. We can make no better use of leisure than to familiarize ourselves and keep ourselves familiar with the glories of the past and the catastrophes in which everything has been shattered. . . . Our lives become richer and past and present illumine one another." KARL JASPERS, WAY TO WISDOM: AN INTRODUCTION TO PhiLOSOPHY (R. Manheim trans., Yale Univ. Press 1954) (1951). Another master humanist- this one writing from deep into the camp of history-reminded us that "What is it, exactly, that constitutes the legitimacy of an intellectual endeavor? . . Even were history obliged to be eternally indifferent to homo faber or to homo politicus, it would be sufficiently justified by its necessity for the full flowering of homo sapiens." MARC BLOCH, THE HISTORIAN'S CRAFT 8 (2004). The only point here, again, is that should legal history aspire to a certain scholarly rigor, it ought to find its legal theoretical foundation. 30. For the view that it does, see Christopher Tomlins, After Critical Legal History: Scope, Scale, Structure, in 8 ANN. REV. L. \& Soc. SCI. 31 (2012). For reflection, from a hermeneutical perspective, on the conditions of possibility of historical knowledge, see DILTHEY, supra note 16, and MICHAEL OAKESHOTT, ON HISTORY AND OTHER ESSAYS (1999).

31. And also the deeply wise David Luban, Legal Modernism: Law, Meaning, And Violence (1997). 
only do so intelligibility using concepts. ${ }^{32}$

However, conceptualism as I understand it is neither committed nor reducible to innate concepts ${ }^{33}$ or to mere inductive or intuitive classifications. ${ }^{34}$ Obviously anchored in the innate ability to create, acquire and deploy concepts, conceptualism is best understood as the view that concepts are vessels that transform the unmediated experiences of consciousness into the possibility of logical thinking. In other words, conceptualism transforms classical metaphysics into logic ${ }^{35}$ by prescribing criteria for apperception of, and communication about, the world. After all, semantics and semantic relationships are already inherently prescriptive. ${ }^{36}$ In this regard, concepts are not just pre-conditions of intelligibility, but constitute intelligibility itself. Reality is intelligible as concepts and relations between concepts. ${ }^{37}$ This is the general point that I take Hegel to be making when he says that "the concept is . . this absolute unity of being and reflection whereby being-in-and-for-itself only is by being equally reflection or positedness and positedness only is by being in-and-for-

32. Conceptual deprivation is therefore an acute form of deprivation. Consider, for example, the damage caused to clear thinking as well as to legal and political life by the deprivation of sustained work on concepts such as state, budget or public office in the American traditions of jurisprudence and legal history.

33. Such as those identified by Kant. ImManuel Kant, CritiQue OF Pure REASON (Paul Guyer \& Allen W. Wood trans., Cambridge Univ. Press, 1999) (1781).

34. Of the Oxford jurisprudence orientation, from H. L. A. Hart to John Gardner, but also of the sophisticated interdisciplinary orientation of, for example, Nicola Lacey, see HART, supra note 5 and H. L. A. Hart, The Authority of Law: EsSAys on LAW AND Morality (2009); John Gardner, LAW AS A LEAP OF FAITH (2012); Nicola Lacey, Analytical Jurisprudence versus Descriptive Sociology Revisited, 84 Tex. L. ReV. 945 (2006) and Nicola LACy, In SEARCH OF CRIMINAL ResponsibiLity (2016).

35. See the reconstructions of Hegel's Logic in Robert B. PIPPIN, Hegel's Realm of Shadows (2019).

36. See Hilary Putnam, Renewing Philosophy (1992). Distilling Kant for inferential pragmatic purposes, Robert Brandom speaks of "the understanding, the conceptual faculty, [as] the faculty of grasping rules - of appreciating the distinction between correct and incorrect application they determine." Such rules are mostly implicit but never absent in inferential discourse, which then emerge as the normative practice that it is. "The structure of those practices can be elucidated, but always from within normative space, from within our normative practices of giving and asking for reasons." The logical labor of conceptualism is, in large part, that of increasingly "making explicit the implicit structure characteristic of discursive practice as such." ROBERT B. BRANDOM, MAKING IT EXPLICIT 8, 649 (1998). A convergent point about the inherent rationality claims of speech is made systematically in 1 JURGEN HABERMAS, THEORY OF COMMUNICATIVE ACTION: REASON AND THE RATIONALIZATION OF SOCIETY (T. McCarthy trans., Beacon Press, 1985). Writing from the viewpoint of jurisprudence, Neil MacCormick postulated that in virtue of human nature we are "norm-users." See NEIL MACCORMICK, INSTITUTIONS OF LAW (2009).

37. See further, and from widely different approaches, the "Second Part" of IMMANUEL KANT, CRITIQUE OF THE POWER OF JudGement (Paul Guyer \& Eric Matthews trans., Cambridge Univ. Press, 2006); G. W. F. Hegel, The SCIEnce of Logic (George Di Giovanni trans., Cambridge Univ. Press, 2015) \& Elements of the Philosophy of Right. Op. Cit.; Duncan Kennedy, The Structure of Blackstone's Commentaries, 28 Buff. L. REV. 205 (1979); Pierre Schlag, The Aesthetics of American Law, 115 HARV. L. ReV. 4 (2002); Jules Coleman \& Jody Kraus, Rethinking the Theory of Legal Rights, 95 YALE L.J. 7 (1986); Robert B. Pippin, In What Sense is Hegel's Philosophy of Right 'Based' on His Science of Logic? Remarks on the Logic of Justice, in Hegel's PolitiCAL PHILOSOPHY (T. Brooks \& S. Stein eds., Oxford Univ. Press, 2017); Charles Barzun, Legal Rights and the Limits of Conceptual Analysis, in 26 RATIO JURIS 215 (2013). 
itself." 38 An ancillary question about concepts that the theory of the nature and evolution of law outlined in this article takes no position on is whether concepts exhaust, without residues, intelligibility. ${ }^{39}$ Whatever position one takes on this question, it is certainly the case that intelligibility is not reducible to successfully adapted or strategic comportment, including practical or cognitive adaptive comportment.

The Article will now proceed in three Sections. The remainder of Section 1 develops a typology of legal explanations, with focus on grand legal history and theory of legal evolution. The purpose of this Section is to show that full realization of the former's explanatory potential depends on its finding support in the latter. Section 2 outlines core elements of a theory of the nature and evolution of law suited to provide that support for legal history. That outline incidentally explains the role of legal history in the evolution of law. Section 3 concludes the overall argument.

\section{B. Types of Legal Explanation}

Explanations in law can be analytically distinguished into a typology. ${ }^{40}$ Ideal-typically, but seldom as practiced, they differ in viewpoint and scope-enclosed or enclosing — and in timeframe — synchronic or diachronic. In legal evolution, as Section 2 shows, much hinges on the dynamic between enclosed and enclosing, synchronic and diachronic explanations.

Enclosed legal explanation is cabined within the point of view of actors as actors of legal systems who seek to positionally create, develop, deploy, expound, or explain the formal sources of law and their institutions. For our purposes, two subtypes of enclosed explanation matter most: specific legal history and legal doctrine.

Punctual legal history is that which is parochial in space or in time. It is often concerned with one topic, one type or source, or with tracking doctrine in time.

Legal doctrine is the tradition of discourse that conceptually organizesby synthetizing that which is disperse and analyzing that which is clustered - legal sources in ways that incorporate the history of the relevant

38. See HEGEL, supra note 35, at 12 (of the Logic in the Gesammelte Werke), italics omitted.

39. For a view that cognitive experience has no "non-conceptual content," see JOHN MCDOWELL, MIND AND WORLD (1994).

40. Compare and contrast the typology presented in this Article with the generous and helpful Martha Minow's underground Fieldguide eventually published as Martha Minow, Archetypal Legal Scholarship: A Field Guide, in 63 J. LEGAL EDUC. 65 (2013) and with the compelling argument against thinking about law in terms of the strict inside/outside "dichotomy" in Charles Barzun, Inside/Out: Beyond the Internal/External Distinction in Legal Scholarship, 101 VA. L. REV. 5 (2015). 
concepts, use of institutional idioms and customs, processing of functional demands, and infusion of values. ${ }^{41}$ In its historical dimension, doctrine engages in historical analysis of law as distinguishable from punctual legal history. Doctrine is the predominant form of discourse adopted by anyone whose action orientation - by profession or circumstances - is legal. More so than in any other type of legal explanation, it is in the intellectual and discursive vessel of doctrine that the form of law - and legal formalismordinarily travels. ${ }^{42}$

Conversely, enclosing legal thought theorizes the origins, logic, functions, value, structuration, meaning, or evolution of law, including legal actors' enclosed orientation. Enclosing legal explanation admits several subtypes. For our purposes, I focus on two of them: grand legal history and theory of the nature and evolution of law.

Enclosed and enclosing explanations may privilege either law's synchronic or diachronic dimensions. Synchronic explanations focus on time-undilated features of legal phenomena, including legal doctrine, and whether a phenomenon is temporally placed in the past, present, or future. Diachronic explanations focus instead on time-dilated features of legal phenomena so that one phenomenon P1 is at least in part explained in light of another phenomenon $\mathrm{P} 2$ placed in $\mathrm{P} 1$ 's past or future.

Enclosed-synchronic legal doctrine and enclosed-diachronic punctual legal history are dependent on paradigms of legal thought (to the idea of which I return briefly at the end of this Subsection and then in greater detail in Subsection 2. C.) for their possibility. Less obvious but not less true is that several types of enclosing legal explanation, including that of most schools of contemporary jurisprudence, also rest on paradigms of law for their plausibility and intelligibility.

Keep in mind that this typology is not one of types of legal mind, but rather one of types of explanations that legal minds produce. Aquinas, Bacon, Kant, Savigny, Hegel, Jhering and Holmes all authored doctrinal explanations in addition to other types of explanation they are best known

41. This broader definition benefitted from reflection upon this one: "Legal doctrines do not fulfill their synthesizing function simply by conjoining pre-existing legal rules. Nor do they invent legal rules. Rather, they redescribe a particular legal area in order to provide a clearer context in which legal rules can operate. As a result, there are two requirements for determining the value of a doctrinal theory. The first is its ability to mirror intuitions about the just resolution of legal cases. The second is its ability to provide simplicity and clarity to a particular area of law. Specifically, does it describe the landscape in such a way that the use of a few rules will result in relatively determinate outcomes." Catharine P. Wells, Langdell and the Invention of Legal Doctrine, 58 BUFF. L. REV. 551, 617 (2010).

42. This point about doctrine and the form of law requires further specification, especially so in light of the two examples of legal history in Subsection 1.C below. That specification will have to wait until Section 2(C), though. 
for.

In any event, the typology may be spatially represented in a graph showing the three axes of viewpoint, scope, and timeframe. Closest to the vertex, we find enclosed-synchronic everyday doctrine; next along the timeframe axis, we find the enclosed-diachronic explanation characteristic of, say, interpretive accounts of legal doctrines, sources, institutions, and events that rely on their unfolding over time in the way they are as law or legal argument. For example, such an enclosed diachronic explanation would interpret a line of judicial precedents in order to make a historical analysis of legal argument. The same space in the graph contains punctual legal history. Now moving along the space formed by the viewpoint and scope lines, we meet enclosing-synchronic accounts of the nature or function of legal language, sources, institutions, doctrines, and actors exemplified by analytical jurisprudence, ${ }^{43}$ law and economics, and law and society. Finally, moving further along the three lines, we find enclosingdiachronic legal explanation characteristic of grand legal history and of theoretical explanations that connect the nature of law to its evolution.

Note that the graph would show no limits in principle to continued enhancement of explanatory capabilities within types; but only with regard to enclosing-diachronic theoretical explanations that connect the nature of law to its evolution would the graph predict unlimited expansion of explanatory powers. ${ }^{44}$

Noteworthy also is that the relationships between types of legal explanation tend to be obscured by the practice of thinking within them. In one example of obfuscation, everyday legal doctrine tends to veil its dependency on intelligibility and communicability upon other types of legal explanation. Another case in point of routine obfuscation is the object of this article: grand legal history tends to obfuscate the extent to which it presupposes theories of the nature and evolution of law, to disregard seeking a coherent connection with one such theory, and in the process to become oblivious of how it too fits in the large scheme of legal evolution. More will be said on this later.

I referred to paradigms in this Subsection. An explanation of paradigms is forthcoming in Section 2(C). For now, note that paradigms of legal

43. For an outstanding example, see Joseph Raz, Two Views of the Nature of the Theory of Law: A Partial Comparison, in 4 LEGAL THEORY 249 (1998).

44. "Her look filled me with awe; her burning eyes penetrated more deeply than those of ordinary men ... It was difficult to say how tall she might be, for at one time she seemed to confine herself to the ordinary measure of man, and at another the crown of her head touched the heavens ... "BOETHIUS, The Consolation Of Philosophy 133 (Hugh Fraser Stewart, Edward Kennard Rand \& S. Jim Tester trans., Harv. Univ. Press, 1973). 
thought emerge and mature by moving and decanting through the types of legal explanation. Both The Great Alliance and The Great Manifold paradigms discussed below began by rising to the enclosing-diachronic level of legal theory before percolating in legal thinking and discourse. ${ }^{45}$

\section{History of Law as Diachronic Explanation}

We now turn our attention to the mode of legal explanation of grand legal history, a vibrant and prolific field of research and writing throughout the world. ${ }^{46}$ While often engrossing, its explanatory powers are not to be taken for granted. In large part, those powers turn on whether grand legal history mindfully consults a suitable theory of the nature and evolution of law. Failure of consultation, coupled with the risk of diminished explanatory power, risks a category mistake: while believing a narrative to be a contribution to enclosing-diachronic legal explanation, the historian is in fact producing an enclosed-diachronic analysis of legal discourse and practice, only every once in a while putting the narrative's head above the surface of the internal viewpoint.

Consider two examples of sweeping revisionist historical narrative, which were selected for how much one learns from them and for how both successfully avoid the category mistake risk by consistently keeping their vistas outside their material of analysis, namely the enclosed legal explanation favored by judges, lawyers, and treatise writers. ${ }^{47}$ The question they raise for us is whether their explanatory promise might be enhanced by a theory of the nature and evolution of law along the lines of the one sketched in this Article.

Take, as the first example, a broad critical account of the rise of "legal formalism" in the nineteenth century United States. ${ }^{48}$ According to this class-conflict-based account, "one of the crucial choices made during the antebellum period was to promote economic growth primarily through the legal, not the tax system, a choice which had major consequences for the

45. To illustrate the point, consider that The Great Alliance paradigm achieved dominance in the midnineteenth century as enclosing-diachronic legal thought and, by the end of that century, it had already settled as enclosed legal explanation, by which point its dependency on enclosing-diachronic legal thought was already largely obscured. Furthermore, in its first 150 years, the attractive and resilient Great Alliance spread throughout the world as transplanted doctrine, law and economics, Kelsenian or Hartian positivism, legal pragmatism and experimentalism, public law idealism, etc., before signs of its exhaustion became as clear as they now are.

46. See, for example of both characteristics, the recent OXford HANDBOOK OF EUROPEAN LEGAL History (Heikki Pihlajamaki, Markus D. Dubber \& Mark Godfrey eds., Oxford Univ. Press 2018) and OXFORD HANDBOOK OF LEGAL History (Markus D. Dubber \& Christopher Tomlins eds., Oxford Univ. Press2018).

47. Any list of similar examples would have to include $1 \& 2$ HAROLD J. BERMAN, LAW AND REVOLUTION (1983 \& 2003) and Franz WiEACKER, A History OF Private LAW IN EUROPE (Tony Weir trans., Oxford Univ. Press, 1995).

48. MORTON J. HORWITZ, THE TRANSFORMATION OF AMERICAN LAW: 1780-1860 (1977). 
distribution of wealth and power in American society."49 The historical context from which legal formalism would rise was that of law before the American Revolution, which reflected the (conceptually confused, I should add) marriage of natural and customary law, being "conceived of as protective, regulative, paternalistic and, above all, a paramount expression of the moral sense of the community."50 That would change over the following several decades, in which "the major direction of common law policy reflected the overthrow of eighteenth century precommercial and antidevelopmental common law values." 51 Why? Because "as political and economic power shifted to merchant and entrepreneurial groups in the postrevolutionary period, they began to forge an alliance with the legal profession to advance their own interests through a transformation of the legal system.... This transformation in American law both aided and ratified a major shift in power in an increasingly market-oriented society." ${ }_{52}$ So much so that "by the middle of the nineteenth century the legal system had been reshaped to the advantage of men of commerce and industry at the expense of farmers, workers, consumers, and other less powerful groups within the society." 53 With the consequence that "not only had the law come to establish legal doctrines that maintained the new distribution of economic and political power, but, wherever it could, it actively promoted a legal redistribution of wealth against the weakest groups in the society." 54 In this account, the economic forces expressed as interests of specific social groups provided the direction of change, and political power (in the hands of those groups as never before) caused the changes. To enshrine the changes, the narrative affirms that merchants, entrepreneurs, lawyers, judges, and jurists resorted to "legal formalism" as the epiphenomenal idea, as the codifier of an ontologically denser "alliance between intellect and power. . . For the paramount social condition that is necessary for legal formalism to flourish in a society is for the powerful groups in that society to have a great interest in disguising and suppressing the inevitably political and redistributive functions of law." 55

This materialist ${ }^{56}$ account of the rise of formalism from the eighteenth to the nineteenth centuries ventures not so much a concept as an approximate specification of formalism as a "tendency ... to seek higher levels of generality and inclusiveness of legal doctrine [which] is one of the more

49. Id. at 15 . Let us leave aside the incorrect differentiation of "law" from "tax system."

50. Id. at 253 .

51. Id. at 253 .

52. Id. at 253 .

53. Id. at 253 .

54. Id. at 254 .

55. Id. at 266 .

56. Inverting the ideas and interest (passions) order - "one the warp, the other the woof of the vast arrasweb of Universal History"- - as in Hegel. G. W. F. HegEL, The PHILOSOPHY OF History 23 (J. Sibree trans., Prometheus Books 1991) (1837). 
important characteristics associated with the development of legal formalism." 57 Central to a "scientific" turn in law, formalism operated "through classification of subjects [by which] it sought to show that law proceeds not from will but from reason." 58 The legal treatise genre embodied this scientific turn, for "through its 'black letter' presentation of supposed 'general principles' of law it sought to suppress all controversy over policy while promoting the comforting ideal of a logical, symmetrical, and most important, inexorable system of law." 59

Thus, as a new constellation of class-embodied economic interests politically succeeded in using blatant instrumentalist approaches to force law into mirroring and promoting their preferences, the time subsequently arrived to enshrine those gains. Accordingly, at that time legal actors and the ruling economic classes strategically shifted "from an instrumental to a formalist legal consciousness." ${ }^{\circ 0}$ Legal consciousness is therefore clearly important - "it is primarily with its underlying legal consciousness that $[\ldots$ it is] concerned" 61 - to this critical legal narrative, as it facilitates an opportunistic marriage between "the rise in the power of the ... legal profession" and "the newly powerful commercial and entrepreneurial interests [ $\ldots$ and their] wish for the first time to 'freeze' legal doctrine and to conceive of law not as a malleable instrument of their own desires and interests but as a fixed and inexorable system of logically deducible rules." ${ }^{2}$ Legal formalism is thus the intellectual place where all these factors converge, but it is epiphenomenal rather than "underlying."

Consider a second master narrative about roughly the same period of United States law, only now one that sets legal consciousness as predominant over material forces and, correctly, rejects the view of formalism as an "aberrational interlude" between instrumentalist approaches to law. The grand narrative plot here is a transition in the structure of legal consciousness from its "pre-classical" to its "classical," nineteenth century formal-integrative version of "a rationalistic ordering of the whole legal universe." 63 The subtype of legal consciousness named "classical legal thought" is presented as having two main characteristics. The first is the view-sincerely or insincerely held by legal actors - that "abstract propositions" are operative. I understand "operative" here to mean that despite their abstractness, propositions allow actors, if not to motivate,

57. Id. at 263 .

58. Id. at 258 .

59. Id. at 258 .

60. Id. at 261 .

61. Id. at 258 .

62. Id. at 258-259.

63. Duncan Kennedy, The Rise and Fall of Classical Legal Thought 7 (2006). Dated 1975, therefore preceding the publication of THE TRANSFORMATION OF AMERICAN LAW, the original manuscript of THE RISE AND FALL received a revised Chapter 1 that post-dates the former. 
at least to justify legal choices and case decisions. The second characteristic is the subsumption of formal sources of law under the abstraction of a "power absolute within its judicially delineated sphere." 64 Classical legal thought led legal actors - again, especially judges and treatise authors- to "experience... the compulsion by which an abstraction dictates, objectively, apolitically, in a nondiscretionary fashion, a particular result." 65

Unlike the previous materialist historical explanation of the rise of formalism, which emphasized the structuring effect of economic forces upon legal consciousness, this second, ideational (cum incipient systems theory) explanation, focuses on the structuring effect of legal consciousness upon legal praxis. ${ }^{66}$ Despite these differences, the two accounts share a general thesis about the turn to legal science: "[f]or a crucial season, that of the transformation of American economic and social life, the thinking of the legal elite was organized neither around the categories of natural right and utilitarianism, nor in the vaguely instrumentalist or nationalist mode. . . . During this period, treatise writers, leaders of the bar, Supreme Court Justices, and the like shared a conception of law that appeared to transcend the old conflicting schools, and to ally the profession with science against both philosophical speculation and the crudities of democratic politics."67

The relative causal relevance given in this second narrative to legal consciousness gives it an overall explanatory enhancement. The attribution to legal consciousness - "the study of the characteristics of [which] holds the key to a large number of the most puzzling aspects of the intellectual history of law"68_ of relative ontological and causal autonomy "as a mediator of the contradictions of experience" 69 opens up to comprehension "the dilemmas of modern legal and political theory," which can only be understood "if we recognize and confront the existence of legal consciousness as an entity with a measure of autonomy. It is a set of concepts and intellectual operations that evolves according to a pattern of its own, and exercises an influence on results distinguishable from those of political power and economic interest." However, "the autonomy of legal consciousness . . . is no more than relative ... [for] the particular concepts and operations characteristic of a period, but also the entity that they

64. Id. at 31 .

65. Id. at 31 .

66. Giambattista Vico taught how consciousness types - poetic, heroic and age-of-men languages, in his terminology - generate the accompanying type of jurisprudence suitable to their presiding archetypes. Giambattista Vico, The First New Science (Leon Pompa ed. \& trans., 2002). His work is yet to receive among contemporary legal theorists and historians the attention it merits.

67. Id. at 7 .

68. Id. at 10 .

69. Id. at 249. Where "[t]he sense of contradiction arises from the persistent existence within consciousness of elements which seem mutually exclusive. These can be inconsistent facts, conflicting emotions, or operative abstractions whose implication contradict one another. Mediation is the reduction of the sense of contradiction by an arrangement of the elements that makes the problem less salient." Id. at 34 . 
together constitute, are intelligible only in terms of the larger structures of social thought and action." 70 In other words, what tempers the weight given to legal consciousness is not an accommodation of materialism, but rather ascendance on the structural-ideational ladder. ${ }^{71}$

The explanatory preeminence of legal consciousness offers greater understanding of the flow of influence in the dyad law and society. The introduction of legal consciousness as "a third tier between interest or power and outcomes... makes it possible to learn things about our present situation which were obscured by the simpler vision of an unmediated interplay of purposes and outcomes"72 such as that of the previous example of grand legal history. The resulting historical insight is compelling, and the saga of ideas that grounds it deserves this lengthy quotation:

[T]his is what happened: Before the Civil War, the legal elite conceived the set of legal relationships that together comprise the American legal system-i.e., private citizen to private citizen, private citizen to state, legislature to judiciary, and federal to state government - as qualitatively distinct from one another and as operated legally according to qualitatively distinct analytic principles-i.e., the common law, sovereignty limited by written constitutions, the equilibrium of forces between separate governmental powers, the union of sovereign states.

During the Classical period, the legal elite conceived these four institutional relationships as four particular instances of a single general legal relation: each of them was an example of the delegation of legal powers absolute within their spheres. The role of the judiciary (its sphere of absolute power) was the application of a single, distinctively legal, analytic apparatus to the job of policing the boundaries of these spheres. The legal system appeared to have synthesized successfully the positivist science of law, natural rights constitutionalism, and Classical Economics.

After 1900, this highly-integrated system began a process of further integration that tended toward the reduction of all legal action to the enforcement of intrinsically just ground rules for economic struggle among private actors. The refinements were a response to attacks by liberals and progressives on the political role of the judiciary, but proved ultimately self-destructive. The triumph of a purely formal theory of marginal utility in economics and the appearance of American philosophical pragmatism undermined the analytic apparatus, leading to the dissipation of faith in the intrinsic justice of

70. Id. at 8 .

71. Across gulfs of style, intellectual references and ideological alignment, Kennedy's history of the emergence of classical legal thought finds kinship in a work such as FRANZ WIEACKER, A HISTORY OF PRIVATE LAW IN EUROPE (Tony Weir trans., 1995).

72. Id. at 8 . 
the rules, and discrediting the notion that they could be objectively developed or applied. The outcome was a disintegration of legal thought into mutually autonomous subcategories different from but somewhat resembling those of the pre-Civil War period, and the recession of the judiciary from the role of guardian of the integrity of fundamental legal relationships.

The rise and fall of Classical legal thought was an integral, necessary event in the current of development within which we live. I reject the conception of "formalism" as an aberrational interlude, marring what would otherwise be a uniform and consistent approach sometimes vaguely denominated "instrumentalism" equally characteristic of the pre-Civil War and post-1937 periods. ${ }^{73}$

Driving legal actors is, therefore, a consciousness that forges belief in the capacity of reason to sufficiently step out of the political and economic fray in order to access an integrative concept of justice and its attending requirements according to a logic of "wills" sovereign within their respective domains and yet null outside of it. ${ }^{74}$ Guarding the boundaries of those domains, ready to act in face of usurpations, was the judge as the protagonist legal actor.

But how, then, is legal consciousness defined? In two ways: according to content and to function. The content-based definition delineates both the cognitive space to be populated with concepts as well as the kinds of concepts that belong within it. It goes like this:

Consciousness refers to the total contents of a mind, including images of the external world, images of the self, of emotions, goals and values, and theories about the world and self. I use the term only in this vague, all-inclusive sense. It defines the universe within which are situated the more sharply-delineated concepts that are the vehicles for analysis. . . . Legal Consciousness is an only slightly more defined notion. It refers to the particular form of consciousness that characterizes the legal profession as a social group, at a particular moment. The main peculiarity of this consciousness is that it contains a vast number of legal rules, arguments, and theories, a great deal of information about the institutional workings of the legal process, and the constellation of ideals and goals current in the profession at a given moment. ${ }^{75}$

The functional definition redefines legal consciousness as a system of premises about law and its historical background. Subsets of those premises often interconnect, creating subsystems. This system and its subsystems operate as a shared background condition of personal opinion formation and action orientation, and of interpersonal intelligibility so that "people can 
have in common something more influential than a checklist of facts, techniques, and opinions." The operational efficacy of legal consciousness is explained in part by the fact that it is "so basic that actors rarely if ever bring [its constituting premises] consciously to mind." 76

In this ideational ecosystem, the subsystems of legal thought vie for hegemony. Left concededly "vague" in this account is what causes the subsystem that eventually congealed as "classical legal thought" to prevail over competing subsystems in replacing "pre-classical" legal consciousness. Offered instead is a description of the general features of legal ideas-which by definition were already internal to legal consciousness - as they come into contact with one another. "Then, abruptly or gradually, a distinct, qualitatively new process took hold of them: they were drawn into the integrating subsystem of Classicism. In the process, they changed. In the process of causing those changes in the parts, the integrating subsystem went through its own transformation of internal structure, a tightening in the mode of interrelatedness," thus "the subsystem evolved as a whole" 77 An incipient systems theory (the system and environment framework) reemerges in the narrative to reinforce the point that the dynamic of ideas within legal consciousness "changed autonomously from, although in response to, what happened outside of it. ... We can identify, and follow through time, clusters of ideas that are entities. They develop, evolve, transform themselves, but are nonetheless somehow 'the same thing,' as opposed to other entities, that they were at the beginning." The historical process of legal consciousness is "thus cast in organic terms." 78

These two grand revisionist narratives successfully used synchronic and diachronic enclosed legal explanations as historical materials for their enclosing-diachronic explanations. In the process, they transformed the interpretation of the United States law in the nineteenth century. The first account, materialist, offered a wide-ranging and yet nuanced and detailed interpretation of economic change driving political change driving normative change. Its explanatory limitations are coextensive with those of materialism, even before the issue of whether it was informed by a general theory of the nature of law and its evolution arises.

As for the second narrative, the 1960s-1980s witnessed the revival of the nineteenth century concern with identifying and clarifying the conscious and unconscious implicit in and of social practice as an essential component of social explanation, and some of that concern was absorbed by historiography. Our second account, ideational, ${ }^{79}$ is one of the most

76. Id. at 11 .

77. Id. at $32-33$.

78. Id. at 32-33.

79. An account that fits well in a long ideationalist tradition in Anglo-American social sciences and 
penetrating, revealing, and original efforts of that revival. ${ }^{80}$ Its greater explanatory power, relative to first account, is a beneficiary of the more precise way it uses and connects concepts and of its consequentially richer structuralism (structuralism as traditionally defined).

In terms of legal explanation, though, it is not enough to describe legal consciousness as the depository of all things legal, with things-legal being circularly defined as those materials which legal professionals deposit in their professional minds, and then to postulate the contextualism of the materials thus deposited that congeal in certain ways because of forces internal and external to the activity of professionals, or the logic of the materials they think and talk about, or some exogenous influence, all of which are left unweighted and underspecified.

What defines a legal actor? Are legal actors the same as legal professionals? What conceptual structures allow the selectivity of materials that will be deemed legal by legal actors? Do conceptual structures predetermine what legal actors will download into their minds? If so, do conceptual structures determine the content of legal consciousness (in

\footnotetext{
historiography as exemplified by J. S. Mill and Quentin Skinner. Mill wrote: "the evidence of history and that of human nature combine, by a striking instance of consilience, to show that there really is one social element which is thus predominant, and almost paramount, among the agents of the social progression. This is, the state of the speculative faculties of mankind; including the nature of the beliefs which by any means they have arrived at, concerning themselves and the world by which they are surrounded." J.S. MILL, A SYSTEM OF LOGIC 641 (1904). Skinner illustrates the point with a sixteenthcentury example: "The merchant cannot hope to describe any action he may choose to perform as being 'religious' in character, but only those which can be claimed with some show of plausibility to meet such agreed criteria as there may be for the application of the term. It follows that if he is anxious to have his conduct appraised as that of a genuinely religious man, he will find himself restricted to the performance of only a certain range of actions. Thus the problem facing the merchant who wishes to be seen as pious rather than self-interested cannot simply be the instrumental one of tailoring his account of his principles in order to fit his projects; it must in part be the problem of tailoring his projects in order to make them answer to the pre-existing language of moral principles." Concluding that: "The story of the merchant suggests two morals. One is that it must be a mistake to portray the relationship between our social vocabulary and our social world as a purely external and contingent one. It is true that our social practices help to bestow meaning on our social vocabulary. But it is equally true that our social vocabulary helps to constitute the character of those practices. To see the role of our evaluative language in helping to legitimate social action is to see the point at which our social vocabulary and our social fabric mutually prop each other up. ... The other moral is that, if there are indeed causal linkages between social language and social reality, to speak of the one as mirroring the other may be to envisage the causal arrows pointing in the wrong direction. As the example of the Elizabethan merchant suggests, to recover the nature of the normative vocabulary available to an agent for the description and appraisal of his conduct is at the same time to indicate one of the constraints on his conduct itself. This in turn suggests that, if we wish to explain why our merchant chose to concentrate on certain courses of action while avoiding others, we are bound to make some reference to the prevailing moral language of the society in which he was acting. For this, it now appears, must have figured not as an epiphenomenon of his projects, but as one of the determinants of his actions." Quentin Skinner, Language and Political Change, in Political Innovation and Conceptual Change 6, 21-22 (T. Ball, J. Farr, \& R.L. Hanson, eds., 1989).

80. To mention just a few: the notions of "paradigm" in THOMAS KUHN, THE STRUCTURE OF SCIENTIFIC Revolutions (1962), of "episteme" in Michel Foucault, Les Mots et les Choses-Une

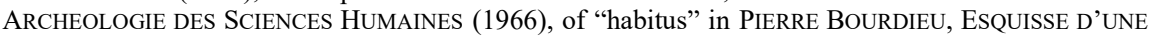
Theorie de la Pratique Precede de Trois Etudes D’Ethnologie Kabyle (1972), and of "formative contexts" in Roberto MANGabeIRA Unger, FALSE NECESSITY: ANTI-NeCESSITARIAN SOCIAL THEORY IN THE SERVICE OF RADICAL DEMOCRACY (1987).
} 
which case the legal consciousness of classical legal thought was a creation of the cognitive formalism of legal science)? If it is the other way around, then we are back to needing an explanation of what determines the selectivity of what constitutes legal materials in the mind of legal actors. If concepts come first, what originated or what warrants the particular conceptual structure that gave rise to "classical legal thought?" What are the keystones of that conceptual structure? What forces operate within the conceptual structure, and in which directions do those forces push so that we can speak of relative autonomy of the legal consciousness that it forges? What forces operate outside the conceptual structure, and in which directions do those forces push? What creates the conceptual structure and the forms of practice it renders intellectually intelligible, or the practically productive, relatively autonomous system vis-à-vis those forces? What about the conceptual structure makes it autonomous, and what about it makes that autonomy relative? What types of legal analyses or explanations does the conceptual structure afford? How do they relate to each other? What is the ontology of the object of the conceptual structure of law? How, when only intelligible through and as a conceptual structure, do legal systems mediate between functional adaptation and axiological steering to achieve both efficiency and legitimacy? What paradigm of legal thought makes possible the adoption of a conceptual structure for law? What are the main tenets of that paradigm? How do legal actors, from the point of view of thought and action, internalize the paradigm and perform it in the world? Do social actors in general need to internalize, or buy into, the paradigm in order for the law of complex societies to generate stability as change or is it sufficient that legal actors, however defined, do so? If so, why do they? And how? And once they do internalize the legal paradigm, how is that manifested in social stability as change?

A general theory of the nature of law and its evolution might place the legal historian closer to answering these questions, thus catapulting the explanatory power of grand legal history. Only then it may turn out that to contend that "[t]he main peculiarity of [legal] consciousness is that it contains a vast number of legal rules, arguments, and theories, a great deal of information about the institutional workings of the legal process, and the constellation of ideals and goals current in the profession at a given moment" 81 is not inconsistent with the other contention that legal consciousness is "so basic that actors rarely if ever bring [its constituting premises] consciously to mind." $" 82$ And the grand narrative will be able to show why that is the case.

In sum, the benefit of having these two remarkable contributions to historiography before us confirms that grand legal history is burdened by

81. KENNEDY, supra note 63 , at 33.

82. Id. at 11 . 
the fact that its explanatory powers track its accoupling of itself to a rigorous and generative theoretical description of the nature and evolution of law. Without this kind of support, what grounding is there to address the challenge of conceivable incommensurability ${ }^{83}$ that may arise between competing (e.g., one materialist and another ideational) grand historical narratives?

My contention, again, is that without the parameters afforded by a theory of the nature and evolution of law, grand historical narratives lack sufficient internal resources to ground their explanatory projects, and therefore any historical revisionism to which they aspire. But once brought to the bar of such a theory, the commensurability presupposed by both critique and revisionism becomes possible, ${ }^{84}$ for a theory of the nature and evolution of law allows historiographical commensurability in virtue of the parameters it provides for judgment of comparative narrative superiority. The assumption here is that, to borrow from MacIntyre's helpful formulation, a historical narrative is superior to a preceding one "if and only if the former . . . enables us to give an adequate and by the best standards we have a true explanation of why the [inferior historical narrative] both enjoyed the successes and victories that it did and suffered the defeats and frustrations that it did." 85 This ability is what is afforded by jurisprudence to legal history.

To generalize the point made above: calls for global, deep or long-term history presuppose the possibility of progress in historical understanding. That progress in turn presupposes a higher order enclosing-diachronic theory of their subject matter, because how else do we tell progress from regress without falling back into justifications by intuition, experience or convention?

83. In the terms specified by KUHN, supra note 80 .

84. The contention here is much more robust than Habermas' suggestion that "an evolutionary theory would, after all, be able to 'inspire' history writing." Jürgen Habermas, History and Evolution, in TELOS 39, 43 (D.J. Parent trans., 1979). Note, on the other hand, that I do not call for a stealth conflation in the form of a "reconciliation" of historiography and general theories of the nature and evolution of law, such as Unger understandably does in the context of approaching core questions of social theory via the method of comparative-historical analysis - "I take seriously the need to work toward a reconciliation of generalizing theory and historiography." UNGER, supra note 5, at 45. See also supra note 78.

85. Alasdair MacIntyre, The Relationship of Philosophy to Its Past, in PHILOSOPHY In History: Essays IN THE HistoriogRAPHY OF PHILOSOPHY 31, 43 (Richard Rorty, J.B. Schneewind \& Quentin Skinner eds., 1984). Bernard Williams offers a similar formulation, of what he names "vindicatory" explanation, but restricts it to the progress of science, and decrees it inapplicable to the succession of explanations in philosophy: "There is of course a real question of what it is for a history to be a history of discovery. One condition of its being so lies in a familiar idea, which I would put like this: the later theory, or (more generally) outlook, makes sense of itself, and of the earlier outlook, and of the transition from the earlier to the later, in such terms that both parties (the holders of the earlier outlook, and the holders of the later) have reason to recognize the transition as an improvement. ... But in the geographically extended and long-lasting and various process by which the old political and ethical order has changed into modernity, while it was propelled by many crises, they were not in the first instance crises of explanation. They were crises of confidence or of legitimacy, and the story of how one conception rather than another came to provide the basis of a new legitimacy is not on the face of it vindicatory." Bernard Williams, Philosophy as a Humanistic Discipline, 75 PHILOSOPHY 477, 487-488 (2000). 
Furthermore, only the contention that neither convention nor personal intuition or self-reported experience suffice as benchmark for commensurability meets the requirements of critical historiography. Critical thought ${ }^{86}$ does not earn its title solely by espousal of theses that contravene the status quo or opinion consensus, or by employing alternative methods of inquiry, or by adopting an intellectual performance that prevailing consensus deems critical, or by being "woke." Critique starts with interrogation of one's reliance on intuition, experience, convention (cognitive, semantic, moral, etc.), or other mechanisms of selfconvincement. ${ }^{87}$ And that for a good reason, for meager as it may seem, critical rigor offers the only hope of sufficiently escaping distorting influences upon one's thinking, and to the extent that escaping is not an option, of knowing that that is the case and why. Absent that, historiographical revisionism is in the opposite, albeit not less lost, predicament of Montaigne's seaman: any wind is right for a seaman who never intended to leave his sheltered harbor. ${ }^{88}$

To be clear, I call for no point in the future of high thought in which grand legal history, on one side, and theories that connect the nature of law to its evolution, on the other, would merge. Nevertheless, the urge for grand legal history to resort to theory is likely to be resisted. And some of that resistance is well-founded, ${ }^{89}$ for the danger of colonization of legal history by evolutionary theories of law is real. The enclosing-diachronic retrospective narrative of grand legal history would in that case collapse under the weight of the explanatory demands of its sibling, enclosing-diachronic evolutionary theory.

Similarly, the balance would be negative, were legal history to be subjected to the disciplinary consensus and methodological requirements

86. Critical, in other words, in one of the modern traditions of cognitive, normative or praxis critique from Rousseau and Kant through Hegel, J. S. Mill, Marx, Nietzsche and Freud to de Beauvoir, Foucault, Habermas and Rawls.

87. "How was it not a problem for us that we did not critique our own set of assumptions ... ? How could it not be the case that we two owned and suppressed a set of debatable groundings ... ? John Henry Schlegel, Sez Who? Critical Legal History without a Privileged Position, in THE OXFORD HandBook Of Legal History 561, 562 (Markus D. Dubber \& Christopher Tomlins eds., 2018). Writing on Foucault, Habermas, quoting Nancy Fraser, asks "Why is struggle preferred to submission? Why ought domination to be resisted?" The implications of his genealogy force Foucault to beg the question about the normative basis of social criticism. But as he begs the question, the modern humanistic normative paradigm makes a covert re-entry onto the stage: "if one tries to glean the standards implicitly appealed to in his indictments of disciplinary power, one encounters familiar determinations from the normativistic language games that he has explicitly rejected." Jürgen Habermas, Some Questions Concerning the Theory of Power: Foucault Again, in CRITIQUE AND POWER: RECASTING THE FouCAULT/HABERMAs DeBATE 79, 96 (Michael Kelly ed., 1994).

88. "No wind is right for a seaman who has no predetermined harbor." MiCHEL De Montaigne, The COMPLETE ESSAYS 379 (M.A. Screech trans., Penguin Books 1991).

89. One such example of resistance, in this case from a modernist culturalist position, which declines the call to align history with jurisprudence (or with a "pragmatic" cashing out of history's lessons) is found in Nathaniel Berman, Modernism, Nationalism, and the Rhetoric of Reconstruction, 4 YALE J. L. \& HUMAN. 2 (1992). 
prevalent in comparative-historical analysis. ${ }^{90}$ The textured, nuanced, and methodologically open rather than occluded character of the best historical narrative is not to be lost or disciplined. It is to be unleashed. The argument in this Article is one way of doing that.

\section{THEORY OF THE NATURE AND EVOLUTION OF LAW}

This Section outlines a theory of the nature and evolution of law with a focus on what is most germane to grand legal history. First, it addresses two aspects of the theory of law: the role of law in the ascent of human history from natural history as well as law's irreducible will-history-reason triadic nature. It then lays out the elementary structure ${ }^{91}$ of the evolution of law in high-complexity societies. When combined, the evolutionary schema has three concatenate parts: theory, structure, and paradigm.

To reiterate, the explanandum of a theory of the nature and evolution of law is how high complexity societies achieve-when they do-social stability as constant social adaptation and axiological responsiveness through small quotidian and large occasional normative changes in what is a system of law. Without understanding of this background, grand legal history proceeds at its own explanatory peril, for to understand that background is to discern the phenomenon of law in time.

\section{A. Theory}

Historians operate under both explicit and implicit assumptions about the differentiation of human history from natural history. They also either explicitly or implicitly favor macro-structural or micro-individualistic ontological and causal models in their narrative construction. Regardless, a

90. Grand historical narratives share in comparative-historical analyses' interest in macroconfigurational orientation, proof driven case-based research, and temporally oriented analysis. Nonetheless, history is not, and should not be, judged on the scientific truth of its discoveries. See, on comparative-historical analyses, the interventions collected here: ADVANCES IN COMPARATIVE-HISTORICAL ANALYSIS (James Mahoney \& Kathleen Thelen eds., 2015); and here: COMPARATIVE Historical ANALYsis IN THE SOCIAL SCIENCES (James Mahoney \& Dietrich Rueschemeyer eds., 2003). Twentieth century classics of comparative-historical analyses include UNGER, supra note 5; BARRINGTON MOORE, SOCIAL Origins of Dictatorship AND Democracy (1993); and THEDA SKOCPOL, STATES AND SOcial REVOLUTIONS (1979).

91. Positions on matters of social ontology and causation inform, of course, the notion of "structure" as used in this Article. Here, however, is not the place to explain how so. I say only that my use of "structures" takes into account but differs from the traditional structuralism of the Saussure and LeviStrauss tradition. For example, I am not committed to the thesis that identity is not intrinsic, but is rather determined by the whole to which an element is a part. For a contrast, compare the use of "structure" in this Article with Justin Desautels-Stein's, Structuralist and Post-structuralist Legal History, in THE OXford HandBook of Legal History, 549-559 (M. D. Dubber and C. Tomlins eds., 2018) especially. Other helpful interlocutors on the nature of structures include Sally Haslanger, What is a (Social) Structural Explanation?, 173 Phil. Stud. 1 (2016); Fred Dredske, Explaining Behavior: REASONS IN A World OF CAUSES (1991); Frank Jackson \& Philip Pettit, Structural Explanation in Social Theory, in REDUCTION, ExPlanAtion, AND REAlism (D. Charles \& K. Lennon eds., 1992); and a reconstruction of a legal theory classic in Akbar Rasulov, From Apology to Utopia and the Inner Life of International Law, 29 LEIDEN J. INT'L L. 3 (2016). 
helpful schema on the nature and evolution of law must reflect the differentiation between natural and human history while being compatible with structural and individualistic ontologies and causalities. Its objective is to assist legal history in making explicit that which is implicit and obscured, as well as making that which is merely explicit to be so in a reflectively coherent way.

We must start with a question addressed to the first condition of possibility of legal history: why is there any history other than natural history? Why not simply conflate human history with the natural history of Homo Sapiens? In other words, what events lead to the ascent of human history from natural history, such that no account of natural processes is able fully to explain societies? What evolutionary process sparked the initial and thenceforth cumulative differentiation of humanity from the rest of nature? In the sequence, this Subsection discusses ontological and methodological implications of classical answers to this threshold evolutionary question.

Consider the following reconstruction of Hegel's answer to the question of natural/human historical differentiation. From a natural world that is undifferentiated by reason, there emerges consciousness. Thence, the phenomenology of consciousness unfolds (hence its historicity) socially (hence its intersubjective development) toward ever purer conceptualism. This continues until the apex of purely conceptual knowledge in which "[t]his last shape of spirit is that of absolute knowing, the spirit which at the same time gives to its complete and true content the form of self, and as a result realizes its concept as well as remaining within its concept in this realization. It is spirit knowing itself in the shape of spirit, or it is comprehending conceptual knowing." 92 Human differentiation from reason-undifferentiated nature is, however, never absolute, for the same nature (broadly conceived) that served as a foil for the development of conceptual capabilities continues to be the stage for the actualization of selfconsciousness. Only now - self-conscious of its appropriation of the world as concepts and conscious of itself as a knower through concepts - reason remains differentiated from nature, for it remains one with itself vis-à-vis the rest of nature. In simpler terms, what humanizes the species is the evolutionary acquisition of self-conscious, reflective conceptual capabilities thenceforth irreducible to natural adaptive sensorial and behavioral abilities.

Now consider the core of Marx's answer, developed in the context of his articulation of a philosophy of praxis against Hegel's idealism. In that philosophy, human productive practice is labor. Labor-the activity of purposeful transformation of nature according to ideas and needs-begot

92. G. W. F. Hegel, The Phenomenology of Spirit, 427 (Terry Pinkard ed. \& trans., Cambridge Univ. Press 2018) (1807) (italics omitted). 
human history from the general background of natural history. The speculation here is that through laboring activity, "man not only effects a change of form in the materials of nature; he also realizes his own purposes in those materials." 93 Hence, as purposeful expression of human ideas and needs, the material product of primitive labor appears in the world as tangible manifestations of the otherwise opaque and inaccessible contents of consciousness. It is the cumulative and collective process of interposing the product of labor as a buffer between everyday human life and immaculate nature that humanizes the species and creates a social, human world. The products of labor raise a ubiquitous mirror that allows the species to see and become conscious of itself in the artifacts it produces. Hence, all else in social life springs from labor. Consequently, according to Marx, the different epochal modes of labor organization shaped the humanization of the species, and consequently the types of consciousness of each epoch.

Durkheim, in contrast, attributes the humanization of the species to the primitive emergence and posterior transformations of collective consciousness. These factors caused each individual to carry a personal consciousness and partake in a collective one - a phenomenon Durkheim referred to as "the double." 94 Before the double, each individual mind had only instinctual relationships with the self and the environment, which included other members of the group. In the process of evolution, a sense of group identity and belonging developed in the minds of group members - perhaps, Durkheim speculates, from primitive experiences of "collective effervescence"-so that "just as society consecrates men, so it also consecrates things, including ideas." The sense of group identity and belonging lies at the root of the humanization of the species, guiding the evolution of not only social life, but also of human cognition, including the categories of time, space and causation that Kant had attributed to a priori mind constitution. And given the social origin of these categories of thought, "logical discipline is an aspect of social discipline."95

For Weber, the aspects that set the species apart-and consequently steered its evolution away from the rest of nature-was the earned ability to create and seek meaning. Meaning was to be imposed inclusively on the scientific apprehension of nature. The disposition to ascribe meaning accumulated as culture, which installed in the mind the lens through which to perceive, process, and find action orientation in the world of natural and social phenomena. Except for references to coping mechanisms of primitive

93. KARL MARX, CAPITAL 284 (B. Fowkes trans., Vintage Books 1977) (1867).

94. EMIle Durkheim, The Division of LABOR In Society (W.D. Halls trans., The Free Press 1997) (1897).

95. Emile Durkheim, The Elementary Forms of Religious Life, 215, 16 n.19 (K. Fields. trans., The Free Press 1995) (1912). 
minds confronted with phenomena they could not explain much less control, Weber is frugal in his account of the beginnings of this process, but his account of the centrality of meaning-seeking and meaning-giving to the humanization of the species is potent. ${ }^{96}$

Undergirding these four models of natural history/human history differentiation is their normative character. Each in its own way describes a fundamental transformation, the expression of which is the subjection of cognition and action to criteria of validity that are irreducible to natural causality.

These classical hypotheses of humanization processes have further ontological ${ }^{97}$ and methodological implications for a general theory of the evolution of law. A concise articulation of these implications may be presented in the form of a question: is social order the outcome (i) of topdown structural or teleological constraints (such as conceptual schemata, historical modes of labor organization or powerful forms of collective consciousness) upon individual agency, (ii) of bottom-up aggregation of individual practical and cognitive agency (of individuals maximizing interests in terms of adaptive strategies and orienting action in terms of meaning) that congeals as social order, or rather (iii) of some irreducible dynamic between structure, teleology and agency?

Classical answers - including those by Hegel, Marx, Durkheim and Weber - to this question also vary. On one end, there is the assertion that social structures prevail over individual agency. This vision rests on two basic assumptions: first, that agency is ultimately caused, constrained or determined by its structural material (e.g. Marx) or ideational (e.g. Durkheim) embedment; and, second, that the structural context of action is the result of developments before which individual agency is helpless. Answers of this kind claim that social causality at the micro-level of agency can be fully explained by an appeal to the structures that envelop agents.

The opposite end emphasizes agency over structure. The basic assumption of answers of this kind is also twofold. First, structural features of the social world are said to be the aggregate outcome or congealment of individual agency (e.g. J. S. Mill). Second, individual behavior can be explained by a combination of instrumental reasoning, preference hierarchies, opinion, sensibilities, and ideals that are, to a large extent, experienced as autonomously forged or adopted by each individual (e.g. in Mill and Weber). Now it is agency that lies sufficiently beyond the causal control of structures, which, on the contrary, are themselves no more nor less than the densest point of a complex net of individual acts converging

96. See, e.g., MAX Weber, The Protestant Ethic AND the SPIRIT Of CAPITALism (Talcott Parsons trans., Routledge, 2001).

97. This Article is not the place to clarify the concept of ontology used in it. Helpful analysis of the concept is developed in Brian Epstein, A Framework for Social Ontology, 46 PHIL. SoC. SCI. 2 (2016). 
over time. Accordingly, structures are best explained as the outcome of the pattern-creating encounter of a multitude of sufficiently self-determined individual acts.

What these two antipodes have in common is the "subjective" (in the precise sense explained below) focus of their explanations of social ontology. What individuals think and do is either the product of selfgenerated mental processes or of the subjectively experienced influence of the structures they inhabit. Accordingly, any intersubjectivity has to take one of two limited forms: it is either the consideration by individuals in their strategizing of the imagined strategizing of others (as in Hobbes) to the extent that they are relevant to fulfilling a given preference of the former or the intersubjectivity is mediated by the structures they share.

Against the dyad of agency and structure, the past decades witnessed the reemergence 98 of the "intersubjective" in the explanation of social ontology. ${ }^{99}$ Common to intersubjective theories of society is the contention that both social structure and individual agency are aspects of the overall ontology of the social that is created through the communicative interaction and meaning-construction of relevant social agents. Consequently, in an ontologically irreducible way, social structure and individual agency are constituted intersubjectively. One consequence of this intersubjectivity turn in social ontology comes in the form of an epistemological thesis: explanatory capabilities are proportional to success in spelling out the generative role of the "intersubjective" in social reality.

Historians will, by now, have easily mapped the schools of historiography and their controversies onto the problematics of natural history/human history differentiation and of downward (from structures to individuals), upward (from individuals to structures) or intersubjective social explanatory models. But we are now also better positioned to understand how the different pieces of a schema on the nature and evolution of law are historiographically generative.

98. Nineteenth century idealism, from Hegel on, already sought to overcome the subjectivism they deemed excessive or one-sided.

99. See, among many works that span the decades and in addition to relevant references already cited, Peter L. Berger \& Thomas Luckmann, The Social Construction of Reality (1967); John Searle, The Construction of Social Reality (1995) and John Searle, Making the Social WORLD (2010); and BRIAN EPSTEIN, THE ANT TRAP: REBUILDING THE FOUNDATIONS OF THE SOCIAL SCIENCES (2015). Habermas conceives this intersubjectivity in terms of communicative action: "the communicative model of action does not equate action with communication. Language is a medium of communication that serves understanding, whereas actors, in coming to an understanding with one another so as to coordinate their actions, pursue their particular aims. In this respect the teleological structure is fundamental to all concepts of action. Concepts of social action are distinguished, however, according to how they specify the coordination among the goal-directed actions of different participants.... In the case of communicative action the interpretive accomplishments on which cooperative processes of interpretation are based represent the mechanism for coordinating action; communicative action is not exhausted by the act of reaching understanding in an interpretive manner... But communicative action designates a type of interaction that is coordinated through speech acts and does not coincide with them." HABERMAS, supra note 36, at 101 . 
With the above in mind, reconsider now two aspects of the nature of law which understanding is central to legal history.

The first aspect is that law embodies the decoupling of human history from natural history. It does so because normativity, as explained above, is the unifying element in the most promising theories of natural/human historical differentiation. Also, recall that law is normativity institutionalized. In the distant past, law was constitutive and a principal mode of manifestation of major normative practices, from kinship and religion, to trade, social hierarchy, and power. In modern times, law has intensified its role in constituting and shaping normative practices. For example, law constitutes and regulates fundamental epistemic, cultural, political, linguistic, and institutional preconditions of contemporary politics, family, art, violence, intimacy, connectivity, science, technology, and the economy.

Whatever understanding of human affairs is afforded by legal history, its potency depends on how explicitly it incorporates the phenomenology of law as a universal, evolving system of intersubjective normative constitution of society that perpetuates the ascent of human history from natural history. In high-complexity societies, recall, this evolving system makes possible the achievement of social stability as constant social adaptation and axiological responsiveness through small quotidian and large occasional normative changes.

Let us now turn to the second aspect of the nature of law- the understanding of which is perhaps the most urgent to legal history - that the norms of a legal system come into existence by acts of individual or collective will that mobilize, in different ways, history and reason. ${ }^{100}$ Operationally, law reaches out from the past into the future through the present; past decisions constantly shape what the future ought to approximate. Hence, law ontologically inhabits the tense intersection of will, reason, and history, which underlie the tension between functional adaptation and axiological aspiration.

In this framework, the concept of will refers to the political power and to the legal authority that allow those who possess them to promulgate the formal sources of law. Power and authority allow issuance of formal sources of law because the subjective expression of preference on the part of their holders is jusgenerative; that is, their preference is intersubjectively interpreted as objective law, to adapt a Kelsenian formulation. ${ }^{101}$ Legal systems of high-complexity societies have themselves assumed

100. This Subsection draws from Paulo Barrozo, The Great Alliance: History, Reason, and Will in Modern Law, 78 LAW \& CONTEMP. PROBS. 1 (2015).

101. The question of identification of sources of law in terms of sociological criteria of recognition or of formal criteria of validity that animated positivistic debates during the last century are to be understood in the context of the will aspect of the ontology of laws. 
(autopoietically) the regulation of this special meaning-attribution process. In any event, in modern times, where ultimate jusgenerative power and authority are traced back to popular consent, will refers first to the concrete, if latent, constituent power of citizens and to their normative authority in and over the structure of the modern state. In legal explanation, will is a trope used to denote not only acts of legislative, judicial or executive lawmaking, but also voting, deference to elections, public opinion, plebiscites and referenda, evolving cultural standards, trends in legislative production across subnational legislative bodies, social movements, current common knowledge, and so on.

The concept of reason refers to instrumental reason (concerned with means-end efficiency, consequences, expediency, costs and benefits), cognitive reason (science, expertise), or normative reason (creation or revelation of the truer meaning of values such as freedom, equality, justice, and dignity). In legal explanation, reason is a trope used in arguments that appeal to the faculty of reason or to reasonable outcomes to explain and justify punctual legal choices as well as to chart or account for broader directions in the development of law.

The concept of history refers to all dimensions of law's diachronicity, from the transtemporality of legal norms to the transgenerational nature of will to the cumulative learning of problem-solving and axiology. It refers also to historical events as they inform the development of the law such as constitutional foundation lores, civil strife, civil or foreign wars, etc. History refers further to historical tradition such as legal precedents or politicalmoral traditions, and historical meaning such as pinpointing time and place of utterances as criteria to ascertain meaning in doctrines of interpretative canon (original intent, e. g.), etc. In legal explanation, history is a trope used in appeals to the past to justify present legal choices or some extant part of the overall legal order.

The triadic nature of law is irreducible. The lesson of the second aspect of the nature of law for legal history is therefore that its narratives must be capacious enough to include how each pillar of the triad as well as the interaction between them bear upon macro-to-micro, micro-to-macro, or intersubjective social explanations of the materials of legal history and the resulting general picture which the historical narrative purports to convey.

\section{B. Structure}

With those two theoretical aspects of the nature of law in place, we now turn to the structure of legal evolution in high-complexity societies. ${ }^{102}$ This

102. In addition to works elsewhere cited in this Article, the following were influential interlocutors in the development of the outline of the evolutionary theory presented here: ANTHONY GIDDENS, THE Constitution of Society (1986); DAVId Garland, Punishment AND Modern Society (1993); Roberto Mangabeira Unger, What Should Legal Analysis Become? (1996); Jurgen 
Subsection identifies the principal elements of the structure in their static roles before modeling them in their dynamic interaction.

Six structural elements stand out: paradigm, formal sources, institutions, functional adaptive pressures, axiological orientation, and actors. Paradigm receives special attention in the next Subsection. Formal sources refer to what intersubjectively counts, on the basis of application of criteria of identification themselves either already legally formalized or still at the stage of political fact, as objective law in a legal system. These normally include a combination of legislation, regulation, writing of intellectual authorities, custom, and judicial precedent. In the legal systems of complex societies, the formal sources of law are further conceptualized in terms of criteria of systemic inclusion/exclusion of source candidates - for example procedures established for the enactment of the particular source having been followed and the source in question not substantively contravening the content of a higher source in the system. Think here of legislative procedures and judicial review. Importantly, the hierarchy of sources combined with criteria of inclusion/exclusion allow the conceptual reductio ad unum at any time of $n$-sources to the singularity of a legal system.

Law is the first institution, for it is generative or constitutive of all other institutions. The derivate institutions of a legal system are myriad. Some are part of the structure of a state or international organization, while others are private or semi-private. The focus here is on the first, public type of legal institution. One obvious but unattended facet of public institutions is that they depend on legal thought-in all its four types of legal explanation (Subsection 1.B) - for meaning, direction, and shared intelligibility in the coordinated, collective activity of those institutions. With the nature of society in mind, Durkheim wrote that "[it] is not constituted simply by the mass of individuals who comprise it, the ground they occupy, the things they use, or the movements they make, but above all by the idea it has of itself." 103 This is equally true of the most important public institutions, which even more so require (legal) thought to ground the idea they have of themselves and to animate their operations. It is from the modes of legal

HABERMAS, BetweEn FACTS AND Norms (William Rehg trans., MIT Press 1998); Duncan Kennedy, Three Globalizations of Law and Legal Thought: 1850-2000, in THE NEW LAW AND ECONOMIC DeVelopment: A Critical APPRAisal (David Trubek \& Alvaro Santos eds., 2006); ClaUde LeVIStrauss, Structural ANTHROPOlOGY (Claire Jacobson \& Brook Grundfest Schoepf trans., Basic Books 1963); Alan Watson, The Evolution of LaW (1989); Gunther Teubner, LaW AS AN AUTOPOIETIC SYSTEM (Anne Bankowska \& Ruth M. Adler trans., Blackwell 1993); IMMANUEL KANT, Idea for a Universal History with a Cosmopolitan Purpose, in KANT: POLITICAL WRITINGS (H.B. Nisbet trans., Cambridge Univ. Press 2d ed. 1991); AleXis TocQueville, The ANCIEN Regime AND the FRENCH REVOlUtion (Arthur Goldhammer trans., Cambridge Univ. Press 2011); Chris TORNHILl, A Sociology of CONSTitutions: CONSTitutions AND STATE LEgITIMACY IN HistoricalSociological Perspective (2013); and Talcott Parsons, The Evolutions of Societies (1977), as well as the additional writings collected in Part IV of TALCOTT PARSONS ON INSTITUTIONS AND Social Evolution (Leon H. Mayhew ed., Univ. of Chicago Press 1982).

103. DURKHEIM, supra note 95 , at 425. 
explanation that those institutions derive and through which they distribute what one author called the "deontic powers" of institutions. ${ }^{104}$ The upshot is that the operation of the institutions of legal systems depends on legal thought, and legal thought depends on the institutions of law to survive and thrive. Hosting institutions and hosted legal thought shape each other. ${ }^{105}$

Dynamically, ever-expanding complexity creates unrelenting tail-wind functional adaptive pressures. Unguided by values, responses to those pressures would not stop. They would proceed in axiologically blind ways, surrendering directionality to strategizing, or managerial, or merely participatory, or experimentalist mechanisms. Things can go on for quite some time like that, but the kind of stability as change that the legal systems of high-complexity societies are capable of would not persist as long as it has in some cases were it not for the admixture of values in the process of adaptive responsiveness.

Returning to a point made earlier, legal systems are voracious, sucking in and digesting not-yet-legal norms, expectations, modes of collective organization, problem-solving strategies, customs, power-grabbing strategies, concentrative and decentrative distributive plans, processes of identity formation and dilution, spatial and temporal organization, etc. In this process of permanent institutionalization, social stability as constant social change takes on the form of law's capacity to receive and process functional adaptive pressures and axiological demands. The choices about which functional adaptive pressures are selected, and how they are responded to, generate social instability unless and until axiological orientation sufficiently guides or constrains those choices. Those considerations ground the contention that social stability as constant social adaptation and axiological responsiveness is achieved through small quotidian and large occasional normative changes.

Furthermore, at this late stage of legal evolution, the conceptual structure of law is itself a source of axiological demands. Axiological orientation comes into this picture as new values (or new conceptions of older values) clash within existing legal fora. This process is inherent in the triadic willhistory-reason nature of law, which unleashes reflective ${ }^{106}$ pushes within modes of legal explanation. Indeed, at any given point in time, the extant norms of a legal system can be construed as manifestation of policies that embody value choices. Thus, at any point in time, any area of legal

104. John Searle, What Is an Institution?, 1 J. Institutional ECON. 1, 1 (2005).

105. This is a point I make in detail in Paulo Barrozo, Institutional Conditions of Contemporary Legal Thought, in SEARCHING For CONTEMPORARY Legal ThOught (Christopher Tomlins \& Justin Desautels-Stein eds., 2017).

106. There is not an opportunity here to digress on the concept of reflectivity. I have deployed the notion of "reflective push" in Paulo Barrozo, Cruelty in Criminal Law: Four Conceptions, 51 CRIM. L. Bull. 5 (2015). In addition to the works by Kant and Hegel already mentioned, I direct the reader to Alessandro Ferrara, Reflective Authority: Rethinking the Project of Modernity (1998) and to UlRich BeCK, ANTHONY GidDENS \& SCOTt LASH, REFLEXIVE MODERNIZATION (1994). 
regulation-e.g., health, education, energy, data, commerce, communications, crime - can be construed as a values domain. This explains the textured nature of domains - sometimes called "regimes" - of regulation. ${ }^{107}$ Their texture-which explains the push for legal history to consider context - is a function of the interaction of will, history, and reason. The push of reflectivity can therefore operate from within any domain even if not triggered by adaptive challenges. Its operation can in turn lead to the perception or realization that the meaning and requirements of the values of the respective regulatory area or regime are not yet sufficiently understood and operative. ${ }^{108}$

The internal push of reflectivity is carried on by legal actors (either directly or by mediating other social actors) pushing onward toward dimensions of values and their requirements that escaped prevailing conceptions at the starting point of the push. ${ }^{109}$ In doing so, they deploy will, history-, or reason-based arguments.

That is why we speak of tail-wind adaptive pressures and axiological steering-edges only figuratively; as a matter of fact, they consist in action by legal actors. In other words, legal actors are the ones who push and steer within the system. As they do so, actors and the structures of a legal system interact without being reducible to each other. ${ }^{110}$

When considered in their dynamism, legal systems are strained by both adaptive and axiological pressures. The sufficiently successful mediation of these pressures explains their ability to produce social stability through continuous law-guided social change. This outcome is, again, simultaneously a sociological and an ethical feat. It is fundamentally important to understand that the mediation takes place in the minds of legal actors, which thenceforth and therefrom manifests in the world.

107. Note that the evolutionary framework outlined in this Article is intentionally capacious enough to accommodate accounts of change within areas of regulation. For example, in his master study of the evolution of penal control, David Garland speaks of two kinds of "transformative forces" in operation: "social, economic, and cultural" society-wide changes of late modernity and the "political realignments and policy initiatives" developed in reaction to the former. DAVID GARLAND, THE CULTURE OF CONTROL 75 (2002). The evolutionary framework expounded here can accommodate and enhance understanding of those factors.

108. I accept Dworkin's point that law institutionalizes certain values and not others. See DwORKIN, supra note 5.

109. What is "reflective" about the push and why it "pushes" cannot be detailed in this Article. I remark only that the process need not be linear and simple, and indeed it seldom is. For an excellent example of non-linear operation of the push, see Maximo Langer's analysis of how the principle of universal jurisdiction over some of the gravest crimes continues to shape domestic and transnational criminal law and procedure even when the principle appears to be in decline. Maximo Langer, Universal Jurisdiction Is Not Disappearing: The Shift from 'Global Enforcer' to 'No Safe Haven' Universal Jurisdiction, in 13 J. INT'L CRIM. JUST. (2015). For an excellent argument about the complexity of normativity as it operates within law, factually negating the explanatory power of accounts that seek the simplicity of reductionisms - for example the principle of "efficiency" operating in the common law — to explain the evolution of law, see Frank Michelman, Norms and Normativity in the Economic Theory of Law, 62 MinN. L. REV. 1015 (1978).

110. In what Reale referred to as a dialectic of implication-polarity. See Miguel ReALE, TeOria TRIDIMENSIONAL DO DIREITO (5th ed. 2003). 
Legal actors are only able to mediate the tension between functional adaptation and value orientation in virtue of the paradigm of law in and through which they think. Legal actors smooth out the corrugation effects of that tension inasmuch as they act out the terms of the covenant between will, history, and reason consecrated by a paradigm of law. It is therefore the structuring effects of paradigms that supply the meaning and intelligibility that make legal action at all viable, especially so in the form of the four types of legal explanation discussed in Subsection 1.B. And it is paradigm-bound legal action that reproduces the structure of the paradigm. In this double effect rests the structure-agency model that best explains the evolution of law.

James Coleman offers a model for agent-structure explanation in which "transition from macro to micro and the transition back to the macro level . . . can be conceived of as the rules of the game, rules which transmit consequences of an individual's action to other individuals and rules that derive macro-level outcomes from combinations of individuals' actions."111 The model is undergirded by a methodological individualism that considers actors as purposeful (therefore rational in Coleman's sense of the term) utility maximizers. Such a model is too simplistic and stifled to capture the nature of law either in its static or dynamic aspects. Only an adequate theory of paradigms of law is able to shed light on the manner in which legal actors, through the different types of legal explanation, think and act out in the world in ways that inextricably weave together adaptation and aspiration.

Returning to the form of law, its complexity and sophistication is further reflected in the fact that no enclosed-synchronic or enclosed-diachronic type of legal thought is able in the long term to keep up, through its own resources, with powerful coordination pressures and normative aspirations. Indeed, in the evolutionary dynamic of law, at times functional responsiveness may leave values behind; at other times, solutions enacted as law will fall short of the requirements of values. When that happens, normative destabilization-small or significant-occurs. ${ }^{112}$ In such situations, patching is required, and the structured yet textured narratives of legal history help equip legal actors with resources to do the work of

\footnotetext{
111. James S. Coleman, Foundations of Social Theory 19 (1994). The so-called "Coleman's Boat" is introduced on pages 8-10.

112. The evolutionary structure expounded in this Article fully accommodates, as part of legal systems stabilizing translation of adaptive complexity into normativity, "moments" of normative crisis. See, e.g., Duncan Kennedy, Form and Substance in Private Law Adjudication, 89 HARV. L. REV. 1685 (1976). In an insightful effort to define "poststructuralism," Bernard Harcourt identifies its core in the "style of critical reasoning that focuses on the moment of ambiguity in our systems of meaning, as a way to identify the ethical choices that we make when we overcome the ambiguity and move from indeterminacy to certainty of belief in our efforts to understand, interpret, and shape our environment." See Bernard Harcourt, An Answer to the Question: 'What is Poststructuralism?' (2007), https://papers.ssrn.com/sol3/papers.cfm?abstract_id=970348 (last visited Oct. 31, 2020). Another incisive reflection on moments of normative crisis, only this time coming from a different cultural camp, is MARY ANN GLENDON, TRADITIONS IN TURMOIL (2006).
} 
recalibration of the relationship between function and aspiration in law. Because of this process, the structure of legal evolution not only accommodates these changes, but even requires legal actors within it to seek, identify and react to deep-cutting ambiguities and turmoil, for it is the actors who are equipped with the tools to process these forces in socially stabilizing ways.

It is unsurprising then that "law and history is the old, established pair, whose passions have ebbed and flowed with new interests and renewed affairs. The Anglo-American story of their relation could be narrated as a political history, connected with the establishment of the autonomy of law from politics or sovereignty within seventeenth-century England." ${ }^{113}$ The narrative structure of legal history facilitates the operations in the mind of legal actors that keep function and aspiration connected or, in moments when functionality and axiology fall out of cadence, that reconnects them.

\section{Paradigms}

In theorizing legal evolution, Hauke Brunkhorst articulates a connection between the adaptive and normative dimensions of legal revolutions. He explains legal revolutions as being "triggered" by linguistically expressed legitimization crises in a context of functional differentiation and class conflict that occasionally leads to leaping normative learning:

Functional differentiation causes certain social problems which the systems themselves cannot solve. These problems consist, in particular, of structural social differences that are latent class conflicts.... Once latent conflicts ... become manifest within the political sphere of public debate and the struggle for public law ...., they will routinely lead to a legitimation crisis. A crisis of legitimization if the trigger of (progressive or regressive) normative learning processes of the affected society as a whole. In an extreme case, a crisis of legitimization can cause revolutionary change. The great legal and constitutional revolutions, therefore, are the paradigmatic cases of a collective learning that is normative." 114

In this model, legal revolutions "are not the result of gradual or incremental change that leads to the improvement and growth of the adaptive capacity of the society, but of rapid, catalytic or revolutionary change that leads to a new constitutional order." Once in place, the new order operates both as "path-opening and path-directing because it constrains social selection normatively." 115

113. Bernadette Meyler, Law, Literature, and History: The Love Triangle, 5 CALIF. L. REV. 2, 374 (2015).

114. Hauke Brunkhorst, Critical Theory of Legal Revolutions: Evolutionary PERSPECTIVES 59 (2014).

115. Id. (emphasis in the original excluded). 
This aspect of a groundbreaking theory of legal evolution misses three important elements: one micro, another macro, and a third related to the way the micro embodies the macro. The micro element is agency, or more specifically, the precise way in which legal actors, in their daily routines, constrain "social selection normatively." For if that selection is not operationalized by institutionally embedded or institutionally interfacing legal actors as they go about their businesses, how else is it done?

Brunkhorst correctly identifies the process whereby law, as explained above, institutionalizes normativity, both routinely and during transformative or revolutionary moments. In the case of evolutionary leaps, a new constitutional order codifies progressive or regressive normative learning.

However, normative learning occurs also at a higher level of abstraction, one that operates as a precondition of plausibility and intelligibility for the learning at the level of institutionalization. This macro, highly abstracted level of normativity I name paradigms of law. Paradigms are abstract enough to accommodate a range of constitutional designs under them. At the same time, paradigms of law have an institutional vocation: they are abstractions of eminently institutionalizable normativity. Paradigms of law possess vast yet limited affordability. In other words, paradigms of law are carved at the highest levels of enclosing-diachronic legal thought, capable still of decantation all the way down to afford from new constitutional codifications to being operationalized by legal actors as they produce, interpret, enforce, and make claims in law. This is the most important way in which the micro embodies the macro in law.

There have been only two paradigms of law in the entire history of highcomplexity societies: The Great Manifold and The Great Alliance paradigms.

The Great Manifold did not fully consolidate until the thirteenth century, in the wake of the philosophical, demographic, economic, institutional, cultural, political, geopolitical, cognitive, technological, self-referential, and communicative transformations that marked the High Middle Ages in Western Europe. ${ }^{116}$ This paradigm of law brought into a compelling jurisprudential manifold the following: revealed divine will, the will of princes and popes, the will of urban elites in city-states, instrumental, cognitive and normative rationalities, the reception of Aristotelian philosophy, and the historical legacies of ius particulare, Roman law and canon law. 
The intellectual hero of The Great Manifold was Thomas Aquinas, whose classical natural law theory enshrined the triadic will-history-reason nature of law in such a mode as to allow it to coexist with intense religiosity of the type our general culture no longer has access to. The cornerstone of the paradigm is a concept of law as a kaleidoscope of normativity, ${ }^{117}$ resulting in a system presented as the complete ordering of all things. This ordering of all things is achieved by interlocking four types of law - eternal, natural, human, and divine - differentiated by the wills that enact them, their proper jurisdiction, and the mode and stringency of their efficacy. ${ }^{118}$

Aquinas defines eternal law as divine will's rule over "the whole community of the universe . . by Divine Reason." 119 Eternal law includes all laws of nature ruling over the entire realm of physis. The laws of nature have absolute efficacy, as nothing can escape them except per special divine dispensation in the form, for example, of miracles. Nature, passive and unconscious, blindly submits to its governing laws, and in so doing displays the normativity of God's reason.

In contrast to the universal jurisdiction of eternal law over nature, natural law has jurisdiction solely over humankind. It is, strictly speaking, still a subsystem of eternal law, albeit a specialized one for it commands upon legal subjects that, unlike the rest of nature, are active and conscious. Humanity's agency is explained by its limited yet significant partaking in God's rational attributes: "the rational creature is subject to divine providence in the most excellent way. ... [w] herefore it has a share of the eternal reason." 120 Natural law is a discovery of practical reason and binding in human conscience, as required by a humanity whose comprehension of the divine is only deep enough to develop a conscious awareness of human

117. Following a pre-Socratic tradition of distinguishing physis and nomos, Aristotle had already problematized the bipartite nature of political justice: one part natural, the other conventional. In Book $\mathrm{V}$ of Nicomachean Ethics, one reads that "Of political justice part is natural, part legal." ARISTOTLE, NicomacheAn ETHICS, 1134b (W.D. Ross trans., Princeton Univ. Press 1995). One would have to wait until the Renaissance for the divine to release humankind to subjection solely to its own normative scheme. See, e.g., Pico della Mirandola: "We have given you, Oh Adam; no visage proper to yourself, nor any endowment properly your own, in order that whatever place, whatever form, whatever gifts you may, with premeditation, select, these same you may have and possess through your own judgment and decision. The nature of all other creatures is defined and restricted within laws which We have laid down; you, by contrast, impeded by no such restrictions, may, by your own free will, to whose custody We have assigned you, trace for yourself the lineaments of your own nature. I have placed you at the very center of the world... . We have made you a creature neither of heaven nor of earth, either mortal nor immortal, in order that you may, as the free and proud shaper of your own being, fashion yourself in the form you may prefer. It will be in your power to descend to the lower, brutish forms of life; you will be able, through your own decision, to rise again to the superior orders whose life is divine." Giovanni Pico Della Mirandola, Oration on the Dignity of Man 7-8 (A. Robert Caponigri trans., Henry Regnery 1956) (1496). Aquinas's kaleidoscopic normativity stands between Aristotle's and della Mirandola's.

118. I here draw from a relatively more detailed study of Aquinas's natural law in Barrozo, supra note 106. I now work on an expanded version of that study.

119. Thomas Aquinas, Summa Theologiae, question 91, art. 1 (Thomas Gilby trans., Blackfriars 1972) (1485).

120. Id. 
imperfections in comparison to divine perfection. Natural law comes to the assistance of fundamentally imperfect creatures who nonetheless long for the good. It is precisely humanity's use of rational faculties to discover norms that directs agency toward the common good, which uncovers the natural laws of humanity - "and this participation of the eternal law in the rational creature is called the natural law."121 Thus it is the "imprint" on people of a "divine light" that entrusts in them, as the rational segment of God's creation, co-responsibility for the government of the cosmos according to the good. In their possession and use of this natural reason, individuals join God as active participants in the government through law of the universe, although restricted to a small but all-important segment of it: human society. God-speech is law because God speaks only law. His rational creation shares this attribute.

In the natural association of individuals into societies, argues Aquinas, humanity exists as a ruled species; ruled, however, by itself, as co-author with God of the law under which it lives. Now, although natural law binds in conscience, conscience is imperfect. Thus, though universally valid, the efficacy of natural law makes room - as all significant natural law doctrines before and after Aquinas do-for anomie. The imperfection of human conscience enters in two ways. First, as with any higher-level normative system, the generality and universality of the precepts of natural law require both (meaning) determination and (application) particularization, what much later generations lumped under the idea of law's relative indeterminacy. As meaning specification and particular application are operations of fallible human reason, the second cause for potential anomie lies in the interference of passions upon reason, a reminder of humankind's inescapable animal nature, a point that Kant would later pick up on.

Now enters human law (positive law) ${ }^{122}$ as a remedy for the imperfections of human reason's understanding of and compliance with natural law. As it concerns this Article, positive law is how history enters the kaleidoscopic, gapless normative system of the cosmos. Yet human law is derivative of natural law as a logical "conclusion from premises" or as a "determination of certain generalities." 123 This is what later generations would name formalism. Rationally derivative, positive law is a bounded exercise of practical reason. Accordingly, reason remains irreducibly imbricated in the ontology of law. Positive law is thus a human artifact in the service of natural law cognition, voluntary compliance, and enforcement. However, just as natural law suffers from human imperfections, so does positive law. Indeed, and by definition, positive law is fallible rationality applied to mundane affairs. Consequently, it can only aim at a form of perfectibility 
open to "its own particular genus." 124

Moreover, in Aquinas' system positive law cannot and should not cover the entire catalogue of human vices, but only those carrying grave social consequences. ${ }^{125}$ The vices to be repressed by positive law are those affecting the common good, that is, those with a public implication. All vices with private consequences only (or primarily) are to be left alone by positive law. These fall into the proper domain of divine law, the fourth kind of law in Aquinas's jurisprudence. The central point about divine law is that it is divine will mediated by revelation as collated in sacred scripture. Divine law offers knowledge not achieved or even achievable by human reason. Revealed by God through prophets and enshrined in sacred scripture, divine law cannot possibly err. Therefore, divine law, which is universal in reach, can offer untainted insight into the nature of goodness and unimpeachable certainty about which practices and intentions have redeeming value.

Under the weight of Aquinas's authority and influence, The Great Manifold paradigm created the conditions for functional adaptation and axiological steering over centuries of great horizontal and vertical political power dispersion and then rapid consolidation - all in a culture profoundly religious and compounded by demographic, geographic, cultural and economic, etc. complexification. In doing so, it welded will, reason and history in a way that is compatible with the personal experience of faith, the cultural, economic and political importance of religion, and the myriad ways that local and supra-local, secular and religious orders interfaced. The Great Manifold paradigm made it possible for legal actors to experience thinking and acting in the practical tasks of daily life as if doing so with a view to assist humanity - naturally committed to the common good and "ordained" to the end of eternal happiness - in God's plan through the medium of law.

The Great Manifold reigned sovereign for centuries, and remains in the marrow of The Great Alliance paradigm, as evidenced by the resurgence about every other generation of versions of natural law. It came under practical and intellectual attacks that proved ultimately successful only starting in the Renaissance and throughout the Enlightenment, especially under the considerable strain of the Thirty Years War and its political aftermath. Early initiatives, such as Henry VIII's interdiction of the teaching of canon law and Thomist philosophy at Oxford and Cambridge in the sixteenth century, did nothing to challenge the authority of The Great Manifold. All they did was contribute to the stunting - felt to this day - of the conceptual development of the common law. ${ }^{126}$ The Great Manifold 
fully collapsed only under the weight of the polarization of the legal historicism and legal rationalism of the eighteenth century. Yet The Great Alliance paradigm crystalized only in the nineteenth century, and its own settlement of will, reason, and history rests on the evolutionary achievements of the previous paradigm.

The Great Alliance continues to preside over the thought and experience of law today. ${ }^{127}$ Its greatest intellectual feat was to bring together the previously polarized historicist and rationalist currents in legal thought. Its intellectual heroes were Hegel and Savigny. ${ }^{128}$ It enshrined the ideas now familiar to us: national constitutions; popular sovereignty with institutionally channeled popular participation in law and politics; tripartite division of state powers; the availability of safe institutional channels to contest authority; ${ }^{129}$ markets legally constituted under conceptions of free contracting, protected property, and fair transactions; individual and collective rights as mechanisms to recognize and protect values embodied in persons and groups; and institutionalized private and public competition, cooperation, and conflict.

The principal mechanism of The Great Alliance was a compact between not only legal rationalism and historicism, but also that to which will acceded (with will now understood fundamentally as popular will). By the end of the eighteenth century, legal rationalism and historicism were polarized more than ever before. This polarization was largely due to the reception of the French Revolution across the Western Hemisphere. Against this backdrop, the legal rationalism of Hegel conceptualized the historicity of law as the outcome of the cunning operation of reason in the world, or as Emerson saw it, "of the works of this mind history is the record." 130 At the same time, the legal historicism of Savigny appealed to legal reason in order

Coquillette's grand quadrilogy Legal Ideology and Incorporation (I-IV) published in the volumes 61 and 67 of the Boston Univ. Law Review in the 1980's. Maitland saw the loss for medieval English law in escaping being taken over by the Roman law tradition more than compensated for by keeping abbey the autocratic stem that runs in that tradition as he saw it. The influence of his opinion on the matter is essential to explain the persistence of the conceptual delay I mention here. See FrEDERICK WILLIAM Maitland, THE History OF ENGLish LAW BEFORE THE Time OF EDWARD I (2010).

127. I devote relatively less space to The Great Alliance as it was detailed in previous work. I also spare the reader the analysis of how the works of Savigny and Hegel cemented the paradigm for the same reason. I again refer the reader to Paulo Barrozo, The Great Alliance: History, Reason, and Will in Modern Law, 78 LAW \& CONTEMPORARY PROBLEMS 235 (2015).

128. See Friedrich Karl Von Savigny, On The Vocation of our Age For Legislation and JURISPRUDENCE (A. Hayward trans., [publisher] [year]) (1831); 1 FRIEDRICH KARL VON SAVIGNY, System of THE Modern Roman LaW (Holloway trans., Hyperion Press 1993) (1867); and Hegel, supra note 22.

129. The idea of institutionalized Socratic contestation, "a practice that gives institutional expression to the idea that all legitimate authority depends on being grounded in public reasons, that is, justifiable to others on grounds they might reasonably accept." Mattias Kumm, Institutionalising Socratic Contestation: The Rationalist Human Rights Paradigm, Legitimate Authority and the Point of Judicial Review, 1 EUR. J. LEGAL STUD. no. 2, 2008, at [starting page of article], 155.

130. Ralph Waldo Emerson, History, in The EsSEnTIAl Writings of RalPH Waldo EMERSON 113, 114 (2000). 
to scientifically (as legal science) capture and conceptually stabilize legal historical matter.

The resulting intellectual rapprochement of rationalism and historicism was so compelling, prestigious and authoritative that the ruled masses could hardly resist buying into it. The accession of popular will to the compact is the root of whatever stability as constant change that modern societies achieved. Since then, modern law and the main schools of enclosed legal explanation have remained bound to this convergence of reason and history in the face of will. Even the enclosing-diachronic model of legal explanation embodied in grand legal history unfolds within The Great Alliance paradigm.

As constitutional essentials ${ }^{131}$ were carved onto modern institutional imagination by The Great Alliance, legal thought towards the end of the nineteenth and by the beginning of the twentieth centuries became increasingly devoted to retooling the law to meet the perceived needs of the age and its rising social groups. ${ }^{132}$ From then on, good law was considered that which worked as an efficient means to deal with functional adaptive problems, producing social coordination out of the increasing complexity of social challenges. But the real action was in solving problems in ways that were compatible with the values codified by the axiological axis of The Great Alliance.

The bracketing of wholesale questioning of constitutional essentials was therefore rendered plausible by two factors: first, the imaginative authority of the constitutional settlement of The Great Alliance; and second, the urgency with which novel tail-wind adaptive pressures demanded legal institutional responsiveness, leaving little time for institutional or axiological "big thinking." For the legal actors who inhabit and constantly act out The Great Alliance, the background intellectual environment for the evolution of law as a social problem-solving instrument was already firmly in place - as "the conditions for evolution are a product of evolution"133_ by the end of the nineteenth century, as exemplified in the works of Holmes and Jhering. 134

The Great Manifold and The Great Alliance paradigms set, first in legal thought and then in law, the terms for the coexistence through law of stability and change in high-complexity societies.

Any successful paradigm of law must perform normative, functional, and

131. To use Rawls's felicitous expression. See RAWLS, supra note 13.

132. "The debates are over. Controversies over great ideas have subsided. The scene is finally dominated by those whom Oliver Wendell Holmes long suspected to be mere businessmen. Law is a trade. If you are smart and know how to enact your craft, the forthcoming financial rewards will be sizeable. You'd better adapt." Alexander Somek, The Spirit of Legal Positivism, 12 German L.J. 729, 729 (2011).

133. Niklas Luhmann, LAW AS a Social System 243 (K. Ziegert trans., Oxford Univ. Press 2004). 134. For an excellent study of legal instrumentalism in various areas of contemporary United States law and its risks and consequences, see BRIAN TAMANAHA, LAW AS A MEANS TO AN END (2006). 
explanatory tasks. Normatively, a paradigm must offer a vision for how will, history, and reason converge in law as an axiologically legitimate institution. Functionally, a paradigm must facilitate the resolution of society's coordination problems in directions deemed to be normatively legitimate. The explanatory task is to create the conditions of possibility for all enclosed types of legal explanation. The cumulative result of the performance of these tasks is the softening of the tension between adaptation and aspiration, thus sufficiently integrating for the relevant legal actors, as well as social actors in general, the ontology, axiology, causation, authorship, concept and meaning of law through the form of law. ${ }^{135}$

Paradigms of law are necessarily carved at a high level of abstraction. When they fly close to the ground, they do so, for example, as legal formalism. ${ }^{136}$ Starting in earnest by the end of the nineteenth century, formalism underwent relentless criticism, with each generation of jurists aiming to surpass the previous one's anti-formalist credentials. Failing to comprehend the varieties of formalism and the essential role of formalism in high-complexity societies - and the critical-constructive potential formalism holds - anti-formalism generalized an ephebic, caricatured version of formalism - call it formulaic formalism-as formalism tout court. ${ }^{137}$ Often succumbing to the strawman fallacy, critiques of formalism both described and idealized law not as conceptual symphony, but as jazzy improvisation, thus easily falling into the arms of consequentialisms,

135. Much more would need to be said to show, as Habermas attempted to do, that "the normative defeatism to which both lines [action-theoretic and systems theory] of political sociology lead is not simply a result of sobering evidence but of misguided conceptual strategies as well. These strategies lose sight of what political power owes specifically to its formal constitution in legal terms." HABERMAS, supra note 102, at 330. That is left for another context.

136. The literature on legal formalism is enormous. Sociologically, the form of law is neither desirable nor undesirable; form is the vessel in which sophisticated legal orders travel, and formalism is the attitude of the lawyers who travel with it. It is through the form of law that adaptation and valueorientation are processed together, and formalism is the attitude of legal actors that operate the processing. The formalist attitude manifests itself in a spectrum from the more reflective to the more formulaic. The only cogent critique of formalism is the critique of formulaic formalism. For fruitful studies see, in addition to other sources cited elsewhere, Frederick Schauer, Formalism, 97 YALE L.J. 509 (1988); ERnEST J. WeINRIB, THE IdEA OF PRIVATE LAW (1995); ROBERTo MANGABEIRA Unger, The Critical Legal Studies Movement (1986); Martin Stone, Formalism, in The OXford HANDBOOK OF JuRISPRUDENCE AND PHILOSOPHY OF LAW (Jules Coleman \& Scott J. Shapiro eds., Oxford Univ. Press 2004); and Martti Koskenniemi, The Gentle Civilizer of Nations (2004).

137. Not to mention the difficult conciliation in critical legal thought of a critique of formalism and systemic or structural critique of law. Karl Klare thus describes the difficulty: "The radical critics' problem, of course, is that the antiformalist critique constantly collides with and undermines the structuralist perspective. Structural or systemic theories, whether critical or apologetic, seem to require some version of formalism, some claim or assumption that legal orders have an in-built structure (given either by their core philosophical principles or by functional attributes of the social system) that locks in routine legal decision-making. One cannot convincingly attribute observed regularities in legal outcomes to basic systemic principles or functions without at the same time providing some account of the structural constraints on routine legal decision-making. Yet the antiformalist impulse aims precisely to show the pervasiveness of contingency, choice, and personal responsibility in the legal process. It therefore renders problematical all claims of structural constraint." Karl E. Klare, Social Construction and System in Legal Theory: A Response to Professor Preuss, in 12 GERMAN L.J. 1 (2011). 
pragmatisms, and functionalisms of sundry types.

In the post-legal realist age in Europe and the Americas, pointing to formalism as of the essence of law in complex societies may be seen as adventure in staled orthodoxy. This mistake brings to mind the insight that Borges put in the mind of a conservative-" the heresies we ought to fear are those that can be confused with orthodoxy." 138

To briefly recover the significance of formalism - and to set aside the strawman of formulaic formalism-I introduce the notion of criticalconstructive formalism. Rather than rejecting the inherent tension between functional adaptation and the structural integrity that is usually attributed to formalism, critical-constructive formalism embraces the tension by elevating it to its proper intellectual and practical significance. Criticalconstructive formalism explains the form of law as a fundamental element of the conceptual integrity of law understood in its historicist, rationalist, and voluntarist roots.

All that said, the ultimate test for paradigms of law rests in their resilience. They are also tested on their ability to answer questions about the epistemic status of thinking normatively about an object-law-the phenomenology of which includes past-willed commands to guide present behavior into future outcomes. That is why any successful paradigm of law must incorporate a hermeneutic of normative practices from the viewpoint of social actors, and thus constantly recreating law both as the foundation and as the apex of normative praxis.

It may be helpful now to inventory the static and dynamic features of the theory of legal evolution outlined in this Article.

* Legal systems of high-complexity societies are composed of elements that are integrated from the viewpoint of relevant legal actors by functional, axiological, formal, and hierarchical considerations.

* Legal systems are ceaselessly under attack by functional and axiological pressures that create risks of social destabilization. Risks of destabilization refer to functional or axiological factors that cannot be accommodated without normative change-small or large - in the relevant sector of the legal system. Lack of normative change in such cases may generate anomaly, inefficiency, illegitimacy or unresponsiveness that may accumulate or degenerate into destabilization crisis potentially reaching the level of social change as social instability.

* Paradigms of law operate as intelligibility conditions of legal action and thought, and legal actors reproduce a paradigm by thinking with and through it and by acting it out in the world. In the domain 
of law, paradigm is structuring because it holds the capacity to intellectually integrate will, history and reason at the enclosingdiachronic level of explanation, which generates descending levels of explanation capabilities all the way to the enclosed-synchronic level of everyday doctrine. In worldly sites of legal production, interpretation and enforcement, paradigms of law allow legal actors ordinarily to weave together, in the small confines of their roles, functional and axiological responsiveness in ways that are sufficiently efficient and legitimizing. This process collectively and routinely stabilizes legal systems that are under constant risk of social destabilization. Legal history plays an important role in this process of stabilization.

* The greater a destabilization risk, the higher up in the hierarchy of formal sources and further up in the modes of legal explanation legal actors must reach. The escalation of the viewpoint-scopetimeframe of legal explanation may at times be a match to the need for change of meta-norms of conflict resolution, usually accompanied by changes in the constitutional essentials. Twice in the past, escalation reached the point of paradigm formation.

\section{CONCLUSION}

I offered an extended argument to support the conclusion that legal history, especially of the grand narrative type, should, to avoid unrealized explanatory potential, reflectively adopt a general theory of the nature of law and its evolution as part of its methodological commitments. In the case of highly complex societies, any explanation of law in time would fall short without an understanding of how adaptation and aspiration interact. And no actor-centered interpretive historiographical account of law in time is warranted without an understanding of how paradigms of law allow actors to find meaning and solutions within a system of law.

For that purpose, and with grand legal history in mind, I outlined one such theory of the nature of law and its evolution. A secondary argument was that legal history - apologetic or critical, record-setting or sage, specific or sweeping - plays facilitative roles in the stabilization of high-complexity societies.

At the end, legal history emerges doubly burdened. Here is why.

High-complexity societies, as I have argued, are vessels sustaining relentless functional (and largely axiologically) blind tailwind coordination pressures. By itself, responsiveness to coordination stresses seems capable of integrating and adapting societies for some time. However, long-term social coordination, and consequently social stability, requires a trailblazing normative edge that filters and translates functionality into normativity, and stability into order. This is because trailblazing normative edges provide 
embedded social actors with justificatory capabilities to dislocate raw power from social interaction and problem-solving. This dislocation works by selecting which adaptive pressures will receive a response as well as which kinds of responses there will be. Furthermore, axiological pressures are themselves sometimes at the origin of functional pressures.

For example, the twentieth century showed that solutions offered to address housing shortages ranged from the laissez-faire "let-markets-sortit-out," to forced mass relocation, to the constitutional enshrinement of a social right to housing. It were the normative edges of the respective legal systems that steered solutions in one direction rather than in the competing directions.

Under the aegis of legal systems, the stability of high-complexity societies does not depend-as simpler societies once did in comparative terms - on social stasis through normative inertia. On the contrary, highcomplexity societies can only achieve social stability as constant functional adaptation and axiological responsiveness through the kind of small quotidian and large occasional normative changes that legal systems evolved to institutionalize.

Thus evolved, legal systems render social complexity normative. Considered in their static state, the elements of the evolutionary framework - formal sources of law, institutions, functional adaptive pressures, axiological orientation, paradigms of legal thought, and actors - unfold dynamically in a rough historical path. Paradigms of law succeed - when they do - in the task of smoothing out that path in virtue of the appeal of their axiological axes, of their ability to accommodate efficient solutions, and of their explanation-generative powers, whereby the highest form of legal explanation decants all the way down to quotidian legal doctrine in the hands of countless legal actors, each narrowly positioned somewhere in their large legal systems.

Sheltered under The Great Manifold or, later, under The Great Alliance, the form of law codified as legal doctrine the welding of adaptive solutions and values that embedded legal actors had been socialized to deem attractive. As legal actors walk the ground of their legal systems, forms of legal explanation lubricate, including by obfuscation effects, the overall evolutionary structure. Grand legal history achieves its full explanatory potential when grounded in a theory able to account for these phenomena. Therefore, its first burden is to acquire such grounding.

The second burden is elective, as it is one of self-understanding. No legal system, and helpful as they might be, no enclosed-synchronic or encloseddiachronic type of legal thought, are able to keep up in the long term, through its own resources, with powerful coordination pressures and normative aspirations. Enclosed types of legal explanation are unable on their own to stabilize society as normative change due to a recurrent lack of 
sufficient integration between functional adaptation and the axiological steering afforded at their limited level of abstraction. Such situations are potentially destabilizing of societies. When they occur, legal systems benefit from the narratives of legal history to equip legal actors with resources to restore the cadence between function and aspiration in law.

In this role, grand legal history caters to the demands of significant, and yet bounded, reflectivity inherent in paradigms of legal thought. In other words, legal history contributes to paradigm endurance and operation in the evolution of law. Much hinges on legal history's ability to continue to play this role. If anything, it should get better at it. Therefore, it is appropriate, albeit not necessary, for legal history, especially for grand legal history, to understand and own the role it plays in social stability through normative change; to understand that it is an insider, a part of the history of how law evolves to create and sustain social order. ${ }^{139}$

To understand and own its role might haunt grand legal history in a way common to all enclosing explanations in the humanities. Bernard Williams referred to it as the "problem of reflection versus commitment." ${ }^{140}$ For critical historians in particular, does reflective understanding of how their narratives fit in the production of social stability as social order sabotage their commitment to the enterprise of legal history?

A burden, however, is not necessarily a problem. To see this double burden as problematic presupposes a state of vocational enchantment. It presupposes that one would endure the travails of the historiographical craft only if acting under the belief that legal history necessarily has iconoclastic or revolutionary effects. Such a state of vocational enchantment, if it exists, does not befit the gravitas of coming to an understanding of the theoretical requirements of legal history and of how legal history serves the evolution of law, and of carrying on with the craft nonetheless.

139. "Do consider the possibility, indeed the probability, that we are in a story, and collect yourself a bit," as Thomas Mann had Joseph remind his lover. ThOMAS MANN, JOSEPH AND His BROTHERS, 954 (J. E. Woods trans., Alfred A. Knopf 2005).

140. Bernard Williams, Philosophy as a Humanistic Discipline, in 294 PHILOSOPHY 75, 490. 